\title{
UNITED STATES STEEL'S ACQUISITION \\ OF THE GREAT NORTHERN ORE \\ PROPERTIES: VERTICAL FORECLOSURE \\ OR EFFICIENT CONTRACTUAL \\ GOVERNANCE?
}

\author{
Joseph C. Mullin \\ Wallace P. Mullin
}

\section{NBER Working Paper 5662 \\ NATIONAL BUREAU OF ECONOMIC RESEARCH \\ 1050 Massachusetts Avenue \\ Cambridge, MA 02138 \\ July 1996}

We thank two anonymous referees and Paul L. Joskow for helpful comments. We also thank Bruce Allen, Kenneth Boyer, Timothy Bresnahan, Judith Chevalier, Carl Davidson, Robin Prager, Michael Salinger, an anonymous referee, and seminar participants at Georgetown University, Michigan State University, the University of Michigan, Ohio State University, and the NBER for helpful comments on an earlier paper in which we advanced some of these ideas. We also especially thank George Mullin for his contributions to that earlier paper. This paper is part of NBER's research program in Industrial Organization. Any opinions expressed are those of the authors and not those of Sidley and Austin or the National Bureau of Economic Research.

(C) 1996 by Joseph C. Mullin and Wallace P. Mullin. All rights reserved. Short sections of text, not to exceed two paragraphs, may be quoted without explicit permission provided that full credit, including $(\mathcal{C}$ notice, is given to the source. 


\title{
UNITED STATES STEEL'S ACQUISITION \\ OF THE GREAT NORTHERN ORE \\ PROPERTIES: VERTICAL FORECLOSURE \\ OR EFFICIENT CONTRACTUAL \\ GOVERNANCE?
}

\begin{abstract}
This paper examines United States Steel's acquisition by long-term lease of the iron ore properties of the Great Northem Railway. This 1906 transaction, which significantly increased U.S. Steel's already substantial ore holdings, has been characterized by contemporary observers and modern economists as an example of vertical foreclosure. We present quantitative and qualitative evidence to support an alternative view that the lease generated a net efficiency gain, resulting in lower steel prices, as it promoted relationship-specific investment in the exploitation of the ore properties. Quantitatively, we examine the stock market reactions of U.S. Steel, the Great Northern Railway, steel industry rivals, and the railroads, a major steel customer, to the announcement of the lease signing. Strikingly, the railroads had a significant positive excess return. Qualitatively, we examine the terms of the lease and the performance of the parties to document the role of the lease in encouraging relationship-specific investment.
\end{abstract}

Joseph C. Mullin

Sidley and Austin

1 First National Plaza

Chicago, Il 60603
Wallace P. Mullin

Department of Economics

Michigan State University

East Lansing, MI 48824-1038 and NBER 


\section{Introduction}

Ronald Coase has criticized those industrial economists who frequently overlook the efficiency attributes of innovative business practices because their professional training has predisposed them to identifying antitrust concerns. ${ }^{1}$ In the context of vertical relationships within and among firms, such economists tend to view novel contractual governance structures as sophisticated devices designed to stifle competition rather than efficient mechanisms adopted to overcome bargaining failures and to reduce transaction costs. Other economists have followed in the tradition of Coase by questioning the advisability of enforcement actions taken to discourage vertical integration, whether by merger or by contract, on the grounds that the advocates of antitrust enforcement frequently overestimate the risk of anticompetitive effect while underestimating the potential for efficiency gains. Until recently, this view has enjoyed substantial success as antitrust authorities have concentrated their enforcement resources in other areas. Over the past few years, however, both government officials and economists have reconsidered the issue of vertical integration and its potential for dampening competition through market foreclosure. This theoretical and policy reassessment invites an empirical inquiry to determine whether these anticompetitive consequences exist and are widespread.

This paper examines the vertical foreclosure debate in the context of the particular empirical setting afforded by the United States Steel Corporation's acquisition of iron ore properties during the first decade of the twentieth century. In particular, the paper focuses on the most significant ore acquisition of this period, US Steel's procurement by long-term lease of the rights to mine an enormous tract of land on the Western Mesabi Range controlled by the Great Northern Railway (the "Great Northern Properties") and packaged for lease by industrialist James J. Hill² (the "Hill 
Ore Lease"). This paper employs quantitative and qualitative evidence to argue that the Hill Ore Lease was responsible for a net increase in efficiency. Quantitatively, we apply the Eckbo-Stillman event-study methodology to distinguish between two possible effects of the ore acquisition: (1) vertical foreclosure of US Steel's current and potential rivals in the final market for steel (the "foreclosure hypothesis") and (2) efficiency gains (the "efficiency hypothesis"), possibly generated by contractual governance mechanisms designed to promote relationship-specific investment in exploiting synergistic economies. Eckbo and Stillman tested and rejected the market-power hypothesis in the case of horizontal mergers by examining the stock market reactions of product market rivals to a set of merger and antitrust announcements under the assumption of stock market efficiency. Mullin, Mullin, and Mullin (1995) applied and extended this methodology to examine the reaction of downstream customers. The present paper applies the Eckbo-Stillman methodology by analyzing the stock market reaction of customers and steel rivals of US Steel to the public announcement of the signing of the Hill Ore Lease. The reaction of US Steel's customers provides an estimate of the net effect of the vertical transaction on product market (steel) prices.

The results of the event study suggest that the Hill Ore Lease had the net effect of lowering the market price for steel. We then analyze the terms of the lease to uncover additional qualitative evidence of the efficiency enhancing features of US Steel's acquisition of the Great Northern Properties, and to identify the source of the efficiencies created by the ore acquisition. Moreover, this historical evidence provides support for the efficiency rationale, independent of the event study results.

There are several reasons why the Hill Ore Lease presents an appropriate opportunity for evaluating the foreclosure hypothesis. First, the foreclosure hypothesis possesses a surface plausibility since contemporary industry observers, ${ }^{3}$ government officials, ${ }^{4}$ and modern economists, such as 
Parsons and Ray $(1975)^{5}$ have all emphasized the importance of US Steel's control of iron ore ${ }^{6}$ in their analyses of the company's market power in steel. ${ }^{7}$ The acquisition of the Great Northern Properties was of primary significance both because the estimated tonnage of raw ore made the Hill Ore Lease US Steel's most substantial ore acquisition since its formation and because the Great Northern Properties were the last large bloc of the critically important Mesabi Range not already in the hands of mining interests. ${ }^{8}$ Although the Hill Ore Lease was not a complete vertical integration of the Great Northern Properties, it was the effective equivalent since the lease was of indefinite duration ${ }^{9}$ and the parties expected the iron ore to be substantially exhausted upon reversion.

In addition to the historical significance of the Hill Ore Lease and its role in US Steel's perceived vertical foreclosure of rivals, analysis of the Hill Ore Lease may offer persuasive evidence in the contemporary antitrust debate. According to Robert Bork, defenders of the vertical foreclosure hypothesis begin their industry analyses with the artificial premise that both upstream and downstream firms enjoy market power. It is therefore unsurprising that such analyses "establish some possibility of competitive harm from the joining of two vertically related monopolies." US Steel appears to possess this characteristic feature of significant market shares in both the upstream and downstream markets. Thus, the Hill Ore Lease is a natural experiment for testing the foreclosure hypothesis. If US Steel's acquisition of the final large available source of domestic iron ore failed to produce vertical foreclosure, it becomes difficult to argue that vertical mergers involving much less substantial market shares pose such a danger.

The final benefit of examining US Steel's acquisition of the Great Northern Properties is that the Hill Ore Lease can be analyzed as a case study in the choice of contractual governance structures. The negotiations over the lease involved two sophisticated parties ${ }^{10}$ bargaining over extraordinary potential gains in the face of potentially debilitating transaction costs. Consequently, the terms of 
the contract were carefully considered by both parties over the course of several years ${ }^{11}$ and reflected US Steel's accumulated experience in negotiating leases for other ore properties. In addition, unlike most contracts between private parties, significant terms of the Hill Ore Lease were publicly disclosed ${ }^{12}$ and contemporaneously analyzed due to the size of the transaction and its overall significance in setting the terms of future ore acquisitions. ${ }^{13}$ Strikingly, contemporary critics cited particular contractual terms of the acquisition as evidence of the lease's likely anticompetitive motivation and effect.

This paper is organized as follows. Sections 2 and 3 introduce the historical and economic foundations of the analysis. Section 4 presents the stock market evidence. Section 5 offers additional qualitative evidence from the lease and the performance of the parties which supports the hypothesis that efficient contractual governance mechanisms explain the efficiencies generated by the Hill Ore Lease. We also find evidence against the foreclosure hypothesis from examining similar contractual arrangements in which foreclosure is implausible and by evaluating the terms of the Hill Ore Lease from a foreclosure perspective. We conclude in Section 6.

\section{Historical Background}

From its inception in 1901, US Steel was vertically integrated, with estimated iron ore holdings in 1901 of 700 million tons, forty-four times its 1902 production rate. ${ }^{14}$ The estimated ore holdings of the Great Northern Railway ("Great Northern") on the Mesabi Range ${ }^{15}$ were second only to those held by US Steel through its subsidiary, ${ }^{16}$ Oliver Iron Mining Company ("US Steel") ${ }^{17}$ The significance of the Mesabi Range was due not only to the rich iron content of much of its ore, but also because the ore was perhaps ideally suited for low-cost extraction. Located near the surface 
where it could be mined cheaply and efficiently by the strip method, the bulk of the ore was also soft and could easily be loaded directly from the pit into railroad cars for further shipment. Such attractive features of the Mesabi ore were enhanced by recent technological innovations which made the stripping method less physically cumbersome and more energy efficient. ${ }^{18}$

In the years preceding the Hill Ore Lease, both US Steel and the Great Northern began preparing their individual Mesabi properties for the large scale mining, handling, and transportation of ore. ${ }^{19}$ Such preparations were necessary because full exploitation of the rich Mesabi ore lands had been hampered by the scarcity of transportation facilities on some lines, particularly those of the Great Northern. ${ }^{20}$ Dock facilities also were in need of an upgrade to handle greater capacity, a factor which required a long lead-time. ${ }^{21}$

During the years 1901-1906, US Steel embarked on a series of acquisitions of iron properties which included lands on the Mesabi Range. These earlier additions, however, were "completely overshadowed" 22 in October 1906 when US Steel and the Great Northern finally announced agreement on the terms to the Hill Ore Lease after years of sporadic negotiations. According to the terms of the lease, US Steel agreed to pay a base royalty rate of 85 cents per ton of ore with an automatic increase of 3.4 cents each year for the duration of the lease. ${ }^{23}$ The royalty was adjustable on a sliding scale to reflect the quality of ore, as measured by the iron content. ${ }^{24}$ The royalty, however, was only a portion of the consideration. Ore mined on the Great Northern Properties was to be transported exclusively on the Great Northern Railway at the profitable freight rate of 80 cents per ton. ${ }^{25}$

The lease included a "take or pay" provision ${ }^{26}$ in which US Steel committed itself to mine substantial guaranteed minimum tonnages of ore. The guaranteed minimums began at 750,000 tons of ore in 1907 and escalated by an annual increment of 750,000 tons until the guaranteed minimum 
for 1917 was scheduled to reach $8,250,000$ tons..$^{27}$ In subsequent years, the guaranteed minimum would remain at 8,250,000 tons. Because the vast majority of the Great Northern Properties was undeveloped in $1906,{ }^{28}$ the parties anticipated that US Steel would fail to meet its minimum mining obligation in the first few years of the lease and therefore US Steel was permitted to make up the difference in later years. ${ }^{29} \mathrm{An}$ indication of the magnitude of these requirements is that the 1917 guaranteed minimum of 8,250,000 tons was forty-four percent of US Steel's Lake Superior ore production in 1905 , and twenty-four percent of total Lake Superior ore production in $1905 .^{30}$

A final lease term is that US Steel received the option to terminate the lease on January 1,1915 upon giving two years notice. ${ }^{31}$

From 1907 until 1911, US Steel and the Great Northern both fully performed on their contractual obligations under the lease. Furthermore, as will be discussed in Section 5, each party had made substantial investments in mining and transportation operations on the Great Northern Properties. In 1911, however, political events in the form of intense antitrust scrutiny intervened to disrupt their contractual relationship.

The formation of US Steel and its subsequent ore acquisitions attracted the unwelcome attention of the Bureau of Corporations (the "Bureau") which conducted an exhaustive study of US Steel's position in the Steel Industry. The Bureau submitted its initial report in July 1911, concluding that US Steel exerted a "monopolistic influence" 32 on the steel industry. That influence reportedly rested chiefly on its iron ore holdings in general, and the Hill Ore Lease in particular. The same public concerns which had motivated the Bureau's investigation into the concentration of the iron and steel industry also drew the attention of the House of Representatives which established a special committee in May 1911 chaired by Augustus Stanley (the "Stanley Hearings") to investigate the business practices of US Steel for possible violations of the antitrust laws. 
In the shadow of the Stanley Hearings and facing an imminent dissolution suit by the Department of Justice, US Steel announced in October 1911 that it would exercise its option to terminate the Hill Ore Lease at the earliest possible date, January 1, 1915. The announcement came two years before US Steel was contractually bound to provide such notice. ${ }^{33}$ Most commentators have concluded that US Steel's cancellation of the lease was motivated by fear of antitrust enforcement, ${ }^{34}$ reasoning that cancellation was the single act, "more than any other the corporation could [take, to] forestall a possible action under the Sherman law."35

In spite of US Steel's eleventh hour attempts to avert an antitrust enforcement action, the Department of Justice filed its dissolution suit in October 1911 arguing that US Steel had monopolized the iron and steel industries. US Steel responded aggressively to the suit, and after years of testimony, the district court ruled in favor of US Steel, ${ }^{36}$ a decision later affirmed by the Supreme Court. $^{37}$

\section{Economic Background}

Economic analysis of vertical foreclosure has developed over time in response to increasingly sophisticated understandings of industrial organization and strategies available to market participants. The following discussion briefly surveys the evolution of the patterns and theories of market foreclosure. For the purposes of this paper, the critical observation is that the fundamental effect of any of these hypothesized patterns of successful foreclosure is a restriction of output in both the upstream (iron ore) and downstream (steel) markets with a corresponding increase in price coming at the expense of customers in the downstream product market.

One theory of market foreclosure is that incumbent monopolists will use vertical integration as 
a "barrier to entry" which compels potential rivals to enter at both levels of production. In this context, the acquisition by US Steel of a sizeable share of an essential input restricted entry. As the trade publication Iron Age remarked,

With the Great Northern ores in other hands the Steel Corporation's position might one day be disputed; if they were held without development they might become the basis of strong new competition. $^{38}$

Closely related to entry barrier analysis is the strategy of "raising rivals" costs," outlined by Krattenmaker and Salop (1986). Under this strategy, after acquiring the Great Northern properties, US Steel would restrict iron ore output by refusing to supply ore to other steel producers. Moreover, the remaining independent ore producers would then be able to raise their prices as well. The resulting increase in iron ore prices, and hence in the marginal cost of US Steel's actual or potential steel rivals, would lead to reduced steel output and higher steel prices. This theory assumes that the integrated firm will forego profit opportunities to sell inputs to its downstream rivals. ${ }^{39}$

Finally, in recent work Salinger (1988), Ordover, Salop and Saloner (1990), and Hart and Tirole (1990) have developed models of imperfect competition in which vertical integration can have anticompetitive effects on downstream competition. The most recent and general of these models is Hart and Tirole (1990). Bolton and Whinston $(1991,1993)$ study a complementary set of issues involving not downstream competition but supply assurance concerns. ${ }^{40}$

In the Hart and Tirole setup, there are two upstream firms, $U_{1}$ and $U_{2}$, and two downstream firms, $D_{1}$ and $D_{2}$. The two downstream firms act as Cournot competitors in the final goods market, while the two upstream firms produce a necessary intermediate good at constant marginal costs $c_{1}$ and $c_{2}$. Each upstream firm $U_{i}$ may vertically integrate with the corresponding downstream firm $D_{i}$. After the integration decision, both upstream firms offer simultaneous, secret supply contracts to each downstream unit. ${ }^{41}$ 
They present three variants of their basic model. The most relevant in our context is variant one, ex post monopolization, with iron ore upstream and steel production downstream. Suppose that $U_{1}$ is more efficient than $U_{2}$, i.e. $c_{1}<c_{2}$. Under non-integration, $U_{1}$ will produce more than the monopoly output of the intermediate good, because of its incentive to sell to both downstream firms. ${ }^{42}$ Under vertical integration, the merged entity $U_{1}-D_{1}$ will be able to implement profit sharing, ${ }^{43}$ and so $U_{1}$ will no longer have the incentive to supply $D_{2}$ with more than the quantity of the intermediate good that is optimal for the vertical structure. ${ }^{44}$ Vertical integration is motivated by and has the effect of restricting output in the intermediate goods market. This in turn directly restricts output in the final goods market. ${ }^{45}$

This is an appropriate model in which to consider the vertical relationship between US Steel and the Great Northern Ore properties. First, it begins with an imperfectly competitive market structure both upstream and downstream. Second, the model not only predicts vertical integration and foreclosure, but predicts that it will be the lower cost upstream firm that will be involved in this integration. Since the Great Northern Ore properties were suited for low-cost extraction, it would be represented by $U_{1}$, and US Steel by $D_{1}$. This identification might seem at odds with one feature of the transaction, namely that US Steel acquired the Great Northern Ore properties, not the other way around. But in the Hart and Tirole model it does not matter whether the upstream or downstream firm makes the acquisition, as long as the acquisition takes place. ${ }^{46}$ Finally, the Great Northern acquisition did effect the requisite type of profit sharing, since after US Steel mined the ore it was free to process it internally or sell it to other steel manufacturers.

Transaction cost economists provide an alternative, procompetitive explanation for complex vertical relationships which otherwise might be analyzed as mechanisms for vertical foreclosure. In contrast to the proponents of the market foreclosure hypothesis, transaction cost economists 
"maintain[] the rebuttable presumption that nonstandard forms of contracting, of which vertical integration is an extreme form, have the purpose and effect of economizing on transaction costs." $\mathbf{4 7}^{7}$ Paul Joskow has succinctly summarized the contractual governance literature as follows:

When specific investments represent a significant fraction of the costs of consummating an efficient vertical supply arrangement, the reliance on simple anonymous spot market transactions is likely to be an unsatisfactory governance mechanism for inducing the parties to make the specific investments necessary to yield a least-cost supply relationship. $^{48}$

The source of the failure of the spot market is that relationship-specific investment transforms an ex ante competitive market into an ex post bilateral monopoly with the potential for opportunism by one or both of the parties. Unless this potential is ameliorated, the parties will under-invest in the relationship. A logical alternative to relying on the ex-post spot market would be to write a long-term contract ex-ante, specifying explicitly the investment levels and other actions to be taken by all parties to the exchange in all states of the world. It will not be feasible to write such a complete, contingent contract, however. As Coase (1937) and Williamson (1975) emphasize, the transaction costs involved in attempting to write and enforce such a contract are so severe that contracts are necessarily incomplete, "containing gaps and missing provisions. In particular [the contract] will be silent about the parties' obligations in some states of the world and will specify these obligations only coarsely or ambiguously in other states of the world." 49

In light of the hazards of the spot market and contractual incompleteness, transaction costs economists predict the parties will adopt appropriate contractual governance structures to prevent ex post opportunism and thus promote an efficient level of investment. Thus, transaction costs 
economists would encourage antitrust officials to be attentive to the efficiency enhancing features of contracts which may initially appear to pose antitrust concerns.

Just as US Steel's high market share in steel and ore production makes vertical foreclosure a plausible explanation for the Hill Ore lease, the importance of relationship-specific investments in this environment makes efficient contractual governance a plausible alternative explanation. Of Oliver Williamson's (1983) four categories of relationship-specific investments susceptible to ex post opportunism, the two most prominently featured in the acquisition of the Great Northern Properties were physical asset specificity-investments in durable assets which involve design characteristics specific to the transaction; and site specificity-investments in relatively immobile assets located to minimize transportation costs. Moreover, the Ore lease included provisions to address the issue of contractual incompleteness, for example giving US Steel the unilateral option to cancel the lease. We will develop this analysis more fully in section five.

Hart and Tirole (1990) analyze a more involved model of ex post monopolization that incorporates investments by both upstream and downstream firms. These investments are industry-specific rather than relationship-specific, however. The issue of relationship-specific investments is featured more prominently in Bolton and Whinston $(1991,1993)$. Their work is complementary to Hart and Tirole since they choose to assume away any downstream competitive effects of vertical integration in order to isolate the effect of ownership structure on investment incentives. In their (1993) article, there is a single upstream firm, $U$, and two downstream firms, $D_{1}$ and $D_{2}$, which are not product market competitors. Each downstream firm has a customer with (at most) unit demand for the final good. The customer's valuation for $D_{i}$ 's product is $v_{i}\left(I_{i}, s\right)$ for $i=1,2$, where $I_{i}$ is the non-contractible investment undertaken by $D_{i}$, and $s$ is the random state of nature. Investment $I_{i}$ generates a private, non-contractible $\operatorname{cost} c_{i}\left(I_{i}\right)$ to $D_{i} .{ }^{50}$ The final customer's realized valuation $v_{i}$ 
can be fully extracted by the downstream firm if it makes a sale.

Production of the final good by $D_{i}$ requires one unit of the input produced by $U$, but no other inputs. Supply assurance problems are modelled starkly: with probability $\lambda, U$ can only produce one unit. Otherwise, $U$ can produce two units, one for each downstream firm. After investments are sunk and uncertainty is resolved, the sale of the input is determined by a bargaining game patterned on Rubinstein (1982). Under integration, however, the owner can transfer the input between divisions unilaterally.

Following Grossman and Hart (1986), contracts are assumed to be incomplete. In fact, only spot contracting is assumed to be feasible. The integration or ownership decision, and with it the allocation of residual rights of control, affects private and social welfare through changing ex-post bargaining payoffs and therefore ex-ante investment incentives. As Bolton and Whinston (1991) explain, "Ownership thus provides both a protection against the misappropriation of returns and a stronger future negotiating position whenever future trade and production decisions involving the use of the asset have to be made. When the ownership of an asset changes hands, the new acquirer sees his future returns better protected, in particular his marginal contribution to his future returns is better protected." 51

One result is that non-integration leads both downstream firms to under-invest relative to the social optimum. The reason for this under-investment is that through the bargaining process there is ex-post expropriation of part of the return from investing. This parallels Grossman and Hart's result in a bilateral setting. ${ }^{52}$ Bolton and Whinston find that vertical integration increases the investment of the downstream integrated firm and decreases the investment and the payoff of the downstream independent firm. These effects provide the private motivation for vertical integration. The shift in investment patterns that accompanies vertical integration also gives rise to an increase 
in self-supply, i.e., the upstream firm is more likely to supply its downstream division than when that downstream unit was independent..$^{53}$

But not all the results from a bilateral setting carry over exactly to this multilateral setting. Strikingly, Bolton and Whinston find that vertical integration leads the integrated firm to overinvest relative to the social optimum. This over-investment occurs because in some states of the world, the integrated firm earns a positive marginal return on its investment even though the social return is zero. To illustrate, suppose that $U_{1}$ and $D_{1}$ are integrated. Consider the state of the world in which there is only one unit of the input, and $v_{2}>v_{1}$. Ex-post bargaining will result in $D_{2}$ receiving the input at a price of $v_{1}$. As a result, the integrated firm receives a private return to its investment in increasing $v_{1}$ in this state of the world, even though there is no gross social benefit to this investment (since $D_{1}$ does not receive the input).

Bolton and Whinston are not able to make global comparisons about the social desirability of the ownership structures, but they find situations in which there are private incentives for vertical integration to arise although non-integration would be socially preferable. On the other hand, they do find other situations in which vertical integration is socially preferable to non-integration. In particular, if the probability of an upstream shortage is zero $(\lambda=0)$, then vertical integration is optimal. Both the efficiency and foreclosure effects operate in their model through the effect on investment incentives.

The Bolton and Whinston results suggest that one should not immediately identify transaction cost concerns in vertical integration with efficiency-enhancement. Nevertheless, there are several reasons why such an identification seems warranted in the acquisition of the Great Northern Ore properties (Upstream) by US Steel (Downstream).

First, their model predicts that vertical integration is efficient if there is no probability of 
an exogenous upstream shortage. Since the Great Northern Ore properties were so vast, any shortage was years if not decades in the future. ${ }^{54}$ The Hill lease could lead to restriction of iron ore production, of course, but that type of endogenous "shortage" is more consistent with the Hart and Tirole model than the Bolton and Whinston assumption.

Second, the conditions required for an overinvestment effect appear to be extremely limited or absent. In particular, if we identify US Steel as $D_{1}$, what can we say about $D_{2}$ ? In the contemporary trade press, no other steel manufacturer was identified as a possible developer of the Great Northern Ore properties. Rather, it was thought that J.J. Hill himself or some other entrepreneur might enter the steel industry, using the Great Northern properties as a source of inputs. Moreover, because of US Steel's pre-lease holdings on the Mesabi, there were particular synergies generated by consolidating and exploiting those properties jointly. These are all reasons why the costs of supplying the ore to US Steel would likely be lower than supplying the ore to any other steel manufacturer. In the parlance of the model, it is likely that $v_{1}>v_{2}$ for most states of the world. As a result, the overinvestment effect would be unlikely to arise, since it operates through those situations in which $v_{1}<v_{2}$ and so the independent downstream firm, $D_{2}$, receives the input. Absent this overinvestment effect, vertical integration is both privately and socially optimal. Intuitively, if $D_{2}$ is a sufficiently inferior competitor to $D_{1}$ in the input market, then the Bolton and Whinston model mimics the bilateral setting explored in Grossman and Hart.

Finally, Bolton and Whinston assume that vertical integration has no effect on the prices charged to final consumers. A chief concern of contemporary observers was that the lease would affect the competitiveness of the steel market. It seems much more plausible that any foreclosure effect of the Hill Ore lease would be captured in the ex post monopolization result of Hart and Tirole, and therefore would be reflected in higher prices for steel. 
For these reasons, and for the sake of economy of language, we will refer to the efficiency and transaction cost hypotheses interchangeably, and distinguish those hypotheses from the "vertical foreclosure" hypothesis. Bolton and Whinston's theoretical results should still serve as a caveat to such an identification in other settings, however.

Empirical evidence of vertical foreclosure has been limited. Allen (1971) finds that vertical integration of cement and ready-mix concrete firms was justified by executives by reference to foreclosure concerns. ${ }^{55}$ Grimm, Winston, and Evans (1992) analyze railroad route structures that are isomorphic to vertical integration, and find some foreclosure effects. ${ }^{56}$ Chipty (1995) studies vertical integration between program channels and cable system operators. ${ }^{57}$ She finds that foreclosure occurs; integrated cable operators exclude rival channels. But she also finds that consumers nevertheless benefit from integration. Snyder (1995a) and (1995b) utilized the event study methodology to assess vertical foreclosure in the beer and petroleum industries. ${ }^{58}$ He finds some evidence of foreclosure effects. His studies are distinguished from the present one in that he did not examine the stock market reactions of any firms that were final product customers.

\section{Stock Market Evidence}

The principal quantitative approach of this paper is an application of the Eckbo-Stillman event study methodology that has been used to analyze the competitive effect of mergers. We examine the abnormal stock market returns of firms theoretically affected by US Steel's acquisition of the Great Northern Properties. The stock market reactions of these firms to the acquisition shed light on the competing hypotheses.

Under the foreclosure hypothesis, a steel market competitor could either be hurt by its exclusion 
from a source of supply, particularly if the company lacked substantial ore holdings, or helped by the exclusion of potential competitors. ${ }^{59}$ Under the efficiency hypothesis, however, vertical integration would lower US Steel's production costs thus making it a more effective competitor. Steel rivals would therefore be hurt, unless they could replicate the results of US Steel's contractual innovation. This latter possibility appears unlikely since there were particular synergies between US Steel's pre1906 Mesabi holdings and the Great Northern Properties.

Examining only the response of rivals is not very informative, because both hypotheses would explain a negative excess return. This shortcoming may be addressed by examining the abnormal stock market returns of steel customers. The foreclosure hypothesis implies an increase in customer costs and thus a negative return. In contrast, the efficiency hypothesis predicts more vigorous competition and thus a price benefit which would partially be transmitted to the customers. As outlined, the "foreclosure" and "efficiency" hypotheses are not mutually exclusive, a possibility fully acknowledged by the recent foreclosure literature. ${ }^{60}$ But the stock market reactions of customers will represent the net effect of the acquisition on steel market prices. Thus a positive response by steel customers will be sufficient but not necessary to establish that the transaction was welfareenhancing.

These stock market reactions can be estimated in an event study. This paper computes the expected or "normal" return to a security $i$ at time $t$ according to the CAPM, and so the resulting regression equation is:

$$
R_{i t}-R_{f t}=\alpha_{i}+\beta_{i}\left(R_{m t}-R_{f t}\right)+\Sigma \delta_{i s} D_{s t}+\epsilon_{i t}
$$

for $t=1, \ldots T$, in which 
$R_{i t}=$ return from holding one share of firm $i$ 's stock for week $t$

$R_{f t}=$ risk free rate at time $t$

$R_{m t}=$ return on the market portfolio in week $t$

$D_{s t}=$ a dummy variable with a value of one if an event occurs in week $s$, and zero otherwise

$\epsilon_{i t}=$ a serially uncorrelated random disturbance

\subsection{Sample and Data}

This paper uses weekly data from December 2, 1905 to November 3, 1906, 49 weeks yielding 48 weekly returns. ${ }^{61}$

The reactions of four sets of firms are analyzed: US Steel, the Great Northern Preferred, a portfolio of independent steel producers representing US Steel's rivals ("Rivals"), and a portfolio of 39 railroads, excluding the Great Northern, representing US Steel's customers ("Railroads"). ${ }^{62}$

The railroads were by far the largest consumers of iron and steel during this period, ${ }^{63}$ and steel was a substantial input cost for the railroads, constituting approximately 10 percent of their operating costs. ${ }^{64}$ Ideally, responses of other customer groups would be included to compare their response to that of the railroads, but such groups could not be used due to data limitations. The most significant shortcoming from using the railroads as a steel customer group is the complex interrelationship between steel companies and railroads. In particular, steel companies were important customers of the railroads, with railroad charges representing a large portion of the cost of steel. ${ }^{65}$ Yet as we argued in a related context, these other relationships should not bias inferences derived from this event study. ${ }^{66}$ In particular, the Great Northern Ore acquisition could indirectly affect railroad profitability either by affecting the quantity of steel transported by the railroads, or by affecting the quantity of ore transported by the railroads. The former effect, which we have dubbed 
the "railroad-(as)-supplier" effect, "simply constitutes another transmission mechanism through which the quantity of steel production positively affects railroad profits." As a result, it still allows one to infer the net effect of the Ore acquisition on steel industry output, and hence prices. The latter effect, involving the transportation of ore, is unimportant in the present context since the Hill Ore Lease provided for exclusive transportation by the Great Northern, the returns for which have been excluded from the railroad portfolio.

A further complication is that since steel was a durable input for the railroads, an increase in the price of steel would raise not only the cost of future railroad expenditures on steel, but also the value of the railroads' existing capital stock. As long as this capital effect is not too strong, however, this would lower the magnitude but not change the sign of the railroads' stock market response. There are several reasons to believe that the effect on future expenditures would be the main effect. First, the railroads could reap benefits from the enhanced value of their capital only if they could sell off the steel. But recovering steel rails, for example, would involve considerable direct expense and leave the railroads with the choice of replacing the recovered steel rails with an inferior nonsteel rail, or abandoning the track. ${ }^{67}$ Second, at this time the railroads were continuing to make substantial expenditures on steel for track and equipment. This was both to replace depreciated items and to expand their capital stock. The railroads were not to become a declining industry for a decade or more in the future. ${ }^{68}$ Total railroad mileage was expanding through double-tracking and yard-trackage, and wood freight cars were being replaced by steel cars. ${ }^{69}$ Finally, results from our previous study (Mullin, Mullin, and Mullin (1995)) on the US Steel dissolution suit are consistent with our claim that the railroads can serve as an appropriate customer group. In that study we found that the railroads experienced positive (negative) excess returns to a series of events from the dissolution suit that increased (decreased) the probability that US Steel would be dissolved. Of 
course, it is possible that railroads are not an appropriate customer group, and so our inferences in that previous study were incorrect. But it nevertheless constitutes a consistent pattern from a related but not identical setting.

For the market portfolio, we formed an equally weighted portfolio of the 50 stocks composing the New York Times index, with returns corrected for dividends and stock splits. ${ }^{70}$ Half of the stocks in this index were railroads, reflecting the railroads' prominence in the stock market during this period. As a result, unmodified use of this market return would create the problem of endogeneity. As a result, in the estimation we employ instrumental variables. One instrument is the return on an equally weighted portfolio of the nine stocks which were judged to be nonsensitive to changes in the steel industry. ${ }^{71} \mathrm{~A}$ second instrument is the deseasonalized percentage change in the volume of bank clearings, since bank clearings, seasonally adjusted, were an important macroeconomic indicator. ${ }^{72}$

For the risk free rate of return, we employ the imputed weekly rate on 60 day time loans, as reported by the Financial Review. ${ }^{73}$

\subsection{Event Selection}

A common problem of event studies is that an event candidate may have been anticipated by the stock market. The Eckbo-Stillman methodology solves this problem by conditioning on the reaction of the parties directly involved in the transaction. If one or both of those parties have a significant response, then that indicates that the event brought news to the stock market.

The hypothesized event is LEASESIGN, the formal announcement of the signing of the Hill Ore Lease, which occurred during the week ended October 6, 1906. We examined several reports on the steel industry during this period from the weekly trade publication, The Iron Age magazine, 
and daily editions of the New York Times and The Wall Street Journal to determine the event window. The Hill Ore Lease was subject to extended negotiations and many of the general terms of the contract were publicly known prior to the announcement of the signing. ${ }^{74}$ Contemporary news accounts suggest, however, that the formal announcement did release news to the stock market.

A second obvious event candidate, which we do not explore further, is US Steel's 1911 announcement of its cancellation of the Hill Ore Lease. In a prior study, cancellation of the lease generated an 18 percent negative excess return for the beneficiaries of the lease, the Great Northern Ore Certificate Holders. ${ }^{75}$ The source of the loss is indeterminate, however, because the excess negative return could signify either the forfeiture of a share of future monopoly rents pursuant to the foreclosure hypothesis, or a capital loss incurred on sunk relationship-specific investments under the efficiency hypothesis. Moreover, the source of the stock market reactions of US Steel, steel rivals, and the railroads is also indeterminate because of the circumstances under which US Steel surrendered control of the Great Northern Properties. The lease cancellation had multiple, possibly conflicting market power effects: (1) it brought about a short-term deconcentration of the iron ore market; (2) it may have released information to the stock market about the probability that US Steel would face a dissolution suit and (3) it may have reduced the probability of that dissolution suit and thus increased the probability of long-term concentration in iron and steel markets.

A final comment on our choice of weekly stock return data and a weekly event window. Our initial reason for employing weekly rather than daily data was due to the high time-cost in hand collecting this historical stock market data. Moreover, we believe that although the use of daily return data would likely result in more efficient estimation, that any increase in efficiency would not be substantial.

Since there were six trading days each week during this time period, one might assume that 
daily data would simply multiply the sample size by six, and so the relative efficiency of using daily rather than weekly data would be 2.45 . This must be considered an upper bound, however, since it ignores the serial dependence of the daily observations. Moreover, there is a cost associated with using high frequency data and a narrow event window. As Ellison and Mullin (1995) note, "When the precise timing of an event is uncertain, there is a trade-off in the choice of event window. Two issues arise. The shorter the window, the more precise will be the estimates of the event response. However, the shorter the window, the more likely that the news, and hence the stock market's response, will fall outside the event window."76 Contemporary accounts suggest that news about the Hill Ore lease was released on several days in the week of LEASESIGN, leading up to the day of the formal announcement of the lease. ${ }^{77}$ Of course, with daily data one could estimate a daily market model and compute and cumulate abnormal returns for several days surrounding the event day. But the simulation results by Dyckman, Philbrick, and Stephan (1984) indicate that when there is event-date uncertainty, cumulating residuals from a daily market model "gives results that are essentially equivalent" to using a longer estimation period, such as a week. ${ }^{78}$ Intuitively, if one can observe abnormal performance only at a weekly frequency, then the efficiency gain from using higher frequency data is considerably attenuated.

\subsection{Results}

Table 1 at the end of the paper presents the stock market reactions to LEASESIGN. Focus initially on the excess returns of U.S. Steel and the Great Northern Railway. The economically meaningful and statistically significant positive 4.1 percent excess return by U.S. Steel indicates that news was released to the stock market. 
Although the economically meaningful (but not statistically significant) negative excess return for the Great Northern Preferred is initially troubling, closer examination reveals several satisfactory explanations for the result. First, note that the return analyzed is for Great Northern Preferred stock. The private holders of Great Northern common stock rather than the public holders of Great Northern Preferred would be the principal beneficiaries of excess profits. The division of profits from the Hill Ore Lease in favor of the common stockholders is particularly pronounced because it was generally understood at the time of the announcement that the Great Northern Properties would be spun off and distributed to the common stockholders. ${ }^{79}$ Nevertheless, the Great Northern Preferred enjoyed a robust positive 1.4 percent daily return on the day the lease agreement was announced, a return which contemporary market observers attributed to the agreement. ${ }^{80}$ Presumably the primary source of this positive return was the benefit the Great Northern would continue to derive from the royalties paid on the freight of ore shipped from the Great Northern Properties. Finally, it appears that the announced terms were slightly more favorable to US Steel than had been expected. ${ }^{81}$ These circumstances cumulatively provide persuasive evidence that news was communicated to the market when the lease agreement was announced because although the terms were less favorable to the Great Northern than expected, such negative information was overwhelmed on the day of the announcement by the positive news that a final agreement had been reached.

Having established that news was conveyed to the market by the LEASESIGN event, it is now appropriate to examine the abnormal returns of the railroads and the steel rivals. The right hand side of Table 1 shows the average responses of the railroads and the steel rivals.

The most suggestive result of the event study is the economically meaningful positive excess return of nearly 1 percent experienced by the railroads. This is consistent with the efficiency 
hypothesis. We cannot flatly rule out the foreclosure hypothesis, although the results suggest that any foreclosure effects on steel prices were anticipated to be more more than offset by the efficiency gains passed onto steel customers. In interpreting the magnitude of this effect, recall that steel purchases represented only ten percent of the railroads' total operating costs. Thus a modest excess return on railroad equity implies a far greater expected effect on steel prices.

This excess return of the railroads is statistically significant at the $5 \%$ level against the one-sided alternative, and significant at the $10 \%$ level against the two-sided alternative of zero effect. The one-sided alternative may be more appropriate in this context; the striking feature of these results may be the failure to find a significant negative response by the railroads. There are some sources of concern about this precision, in particular our use of the standard normal distribution to assess the significance of the t-statistics. Since our estimation involves two-stage least squares in a relatively small sample, we cannot readily invoke the asymptotic properties of this estimator. Moreover, stock market returns are known to be distributed non-normally, with fat tails, suggesting that the true significance level for our results is higher than $5 \%$ or $10 \%$. This non-normality is replicated in our sample; we can reject the normality of the railroads' realized returns based on the Shapiro-Wilk W-test. ${ }^{82}$ However, we cannot reject the normality of the residuals from our CAPM regression model; we cannot reject the hypothesis that excess railroad returns are distributed normally, based on the Shapiro-Wilk W-test. ${ }^{83}$ Since our inferences are based on the distribution of excess returns, we are confident in labelling the railroads' results as statistically significant.

The negative excess return suffered by the steel Rivals is also consistent with the efficiency hypothesis, but the result is neither statistically significant nor can it be used to distinguish between the efficiency and foreclosure hypotheses. The foreclosure hypothesis also predicts a negative return for the rivals if relatively unintegrated steel rivals are foreclosed from a source of supply. 


\section{Efficient Contractual Governance Structures}

The results in Section four substantially undermine the foreclosure hypothesis as the sole explanation for US Steel's acquisition of the Great Northern Properties while supporting the efficiency hypothesis. The evidence from the stock market data, however, is unable to identify the source of the gain in efficiency. In this Section, we offer additional qualitative evidence supporting the efficiency hypothesis by analyzing the Hill Ore Lease in search of the source of its efficiency enhancing features. First, we analyze the synergies and cost efficiencies US Steel and the Great Northern sought to achieve by uniting their productive capacities and committing their combined resources to relationship-specific investment in the Great Northern Properties. Second, we compare the governance structures of the Hill Ore Lease with those used by the parties in similar transactions in which market foreclosure is an implausible explanation for the selection of such structures. In particular, after the Hill lease was cancelled, the Trustees for the Ore Properties signed contracts with smaller firms with terms similar to the US Steel lease. Third, we examine the parties' choice of contractual governance structures and evaluate the effectiveness of such structures in producing the desired outcomes by examining the motivation and effect of individual contractual terms. Fourth, we examine the individual contractual terms in light of the foreclosure hypothesis.

\subsection{Durable, Relationship-Specific Investments}

The Hill Ore Lease presented US Steel with an attractive investment opportunity because of the complementary relationship between the Great Northern Properties and US Steel's preexisting ore properties on the Western Mesabi Range. US Steel determined that by uniting the two most substantial tracts on the Western Mesabi it could generate cost-saving economies by taking charge 
of the properties from the beginning and developing the lands according to its long-term mining strategy without being hampered by previous occupiers and outside or adverse interests. ${ }^{84}$

As an illustration of the relationship between the ore lands of the Great Northern and those of US Steel, consider Figure 1, which presents a map of part of the Western Mesabi near Coleraine, Minnesota. ${ }^{85}$ The map identifies the holdings of the Oliver Mining Company, a US Steel subsidiary, and the Great Northern Railway, as of February 1906. Almost all the property between the Northern and Southern boundaries of the range were held by one of these two parties, or held jointly. Moreover, these properties were intermingled, so that unified control could allow for the development of a large, stripped open pit mine for a group of adjacent properties.

Exploitation of the synergies arising from unified development of the Western Mesabi Range, however, first required the parties to agree to a governance structure which would provide both of them with optimal performance incentives over the life of the lease. Efficient extraction of the ore required both US Steel and the Great Northern to make relationship-specific investments, resources the parties would not commit unless ex post opportunism could be averted with ex ante contractual governance structures. Of Williamson's four categories of relationship-specific investments, two categories, physical asset specificity and site specificity, loom large in this context. There is a third element of asset specificity in this environment, that of dedicated capacity.

The need for both physical asset and site specificity in developing the Great Northern Properties was dictated by exogenous circumstances-that is, by the best available methods to extract the ore at minimum cost. US Steel's fundamental approach to the Mesabi ore lands was to plan its ore developments for the indefinite rather than the immediate future, ${ }^{86}$ and thus "to prepare for a long continued period of cheap mining [so] that an entire ore body [could] be extracted at minimum expense." 87 
Due to the long lead-time in the investments made by US Steel, and to a lesser extent those made by the Great Northern, there was an initial delay ${ }^{88}$ in the extraction of ore. By the end of 1908 US Steel had spent approximately $\$ 4$ million on preparing the Great Northern Properties before extracting any ore. ${ }^{89}$ We estimate that US Steel spent at least another $\$ 4$ million in developing mines in the next several years. ${ }^{90}$ If we take $\$ 8$ million as our estimate of US Steel's direct development costs, this would amount to $\$ 84$ million in 1994 dollars. ${ }^{91}$ This $\$ 8$ million investment is overshadowed when compared to US Steel's total capitalization of $\$ 1.4$ billion. But this investment was substantial when comparing to the existing investments in ore properties. In April 1901 US Steel's total book investment in improvements in all iron ore properties was about $\$ 9$ million. ${ }^{92}$

Moreover, the wide variety of asset specific preparations made on the part of US Steel drew the attention of contemporary commentators who noted,

...[US Steel is determined] to open these mines on the most improved and scientific principles possible, and to prepare itself for a vast product at the lowest cost per ton. Vast sums have been spent, and this expenditure is continuing, in the preparation for the beginning of mining operations in the Western Mesaba, enormous stripping operations are in progress, model towns are building, investments of hundreds of thousands of dollars are being made simply to assure the company that its employees shall be of the character desired and shall be reasonably permanent. ${ }^{93}$

These constitute only those investments directly involved in the mining of iron ore. But US Steel could and did make specific investments in its steel manufacturing operations to take advantage of a large, assured supply of ore. An additional motivation for site specific assets was the significance of transportation costs in the production of steel. Consequently, soon after the signing of the 
Hill Ore Lease, US Steel began plans for constructing a large iron and steel plant in the vicinity of Duluth Minnesota to supplement its Gary Indiana plant and to save on transportation costs. ${ }^{94}$ Clearly, the entire value of this investment was not specific to US Steel's relationship with the Great Northern, since the Steel Corporation did control a substantial portion of the Mesabi range on its own. Nevertheless, it is striking that US Steel did not purchase land for the Duluth plant until 1907, (shortly) after the signing of the Hill lease. Plant expenditures totalled nearly $\$ 6$ million by the cancellation of the Hill lease. ${ }^{95}$ Construction continued, and the plant began operations in 1916 after total undiscounted expenditures of $\$ 24.1$ million. ${ }^{96}$ The completed Duluth plant had "an annual capacity of 360,000 tons of finished steel products."97

Clearly, US Steel bore the greater responsibility to invest in completion of the mining operations. The Great Northern, however, was also responsible for making nontrivial relationship-specific investments pursuant to their freight duties. ${ }^{98}$ These latter investments involved both site specificity and dedicated capacity as the Great Northern expanded its dock and track facilities to accommodate the ore shipments. ${ }^{99}$ In particular, the Great Northern constructed track branches to the edge of new mines, so that ore could be loaded directly into the freight cars. ${ }^{100}$ The rolling stock was obviously mobile, but specialized as well. The freight cars moved the ore from the mines to the docks on Lake Superior. James J. Hill testified that the freight "cars are such cars as cannot be used for any other purpose. They are a peculiar car. They are short, and are made to fit the old docks ... the hatches of the vessels were made to fit them." 101 The locomotives were also somewhat specialized to ore traffic, with a Mallet engine, optimized to pull very heavy loads but at relatively low speeds. ${ }^{102}$

As Williamson and the other transaction cost economists have observed, transactions characterized by significant relationship-specific investments will require special contractual governance 
mechanisms to prevent the danger of opportunistic behavior which is characteristic of spot market exchanges involving prior relationship-specific investments. Analysis of the overall structure and specific terms of the Hill Ore Lease will show that the very terms which attracted the condemnation of antitrust officials as insidious instruments of market foreclosure, ${ }^{103}$ were actually efforts to encourage an efficient level of relationship-specific investment by the parties.

\subsection{Lease terms in comparable transactions}

Before analyzing the likely effects of particular contractual terms, we should note that comparable transactions implemented a similar contractual scheme in situations in which market foreclosure is an implausible hypothesis. For example, US Steel used many of the same terms applicable to the Hill Ore Lease when negotiating much smaller iron ore acquisitions. US Steel consistently sought to extend leases which were due to expire to a new term of 50 years or longer. In return for a modest royalty rate, US Steel would agreed to a take or pay provision guaranteeing large annual minimums. ${ }^{104}$ In addition, US Steel employed similar contractual terms in its relationships with suppliers of coal. ${ }^{105}$ The extraordinary abundance of coal makes foreclosure an implausible explanation for the governance structures used in US Steel's coal acquisitions. ${ }^{106}$ The feature these contracts do share with the Hill Ore Lease, however, is the requirement that both parties make relationship-specific investments to create an efficient supplier-producer association. ${ }^{107}$

Even more significant evidence is provided by the experience of the Hill lands after the termination of the lease by US Steel. Soon after the announcement of cancellation, the Great Northern Trustees (the "Trustees") ${ }^{108}$ began making arrangements for continued mining of the ore lands, ${ }^{109}$ to a great extent benefitting from US Steel's sunk investment in improving the facilities both on the mines US Steel had developed and those of adjoining properties. ${ }^{110}$ Initially, the Trustees 
sought to open these lands directly on behalf of the Trust mining the land on its own account. ${ }^{111}$ While continuing to work some mines, the Trustees later reverted to leasing a majority of the ore properties, ${ }^{112}$ seeking reimbursement from lessees for improvements made by the lessors on the lands. ${ }^{113}$

Advocates of the enforcement actions taken against US Steel cite the deconcentration of the Great Northern Properties as evidence that US Steel's ownership of such properties was a substantial barrier to entry for competing iron producers and smaller, integrated steel firms. ${ }^{114}$ The leases such smaller firms entered into, however, contained terms similar ${ }^{115}$ to those contained in the Hill Ore Lease including guaranteed minimums ${ }^{116}$ and mandatory investments. ${ }^{117}$ This suggests that such terms were designed to safeguard genuine efficiencies created by vertical integration.

This provides fairly compelling evidence that US Steel was motivated by concerns of contractual governance rather than market foreclosure in signing the Hill ore lease. Now to consider how this motivation is illustrated by the terms of the lease

\subsection{Specific Lease Terms}

The terms of the ore lease bear striking resemblance to the terms of contracts studied in the transaction cost literature. As a result, an examination of these individual terms recapitulates much of the scholarship on contractual governance undertaken in the past two decades.

\subsubsection{Take or Pay Requirement}

Critics of the Hill Ore Lease appeared particularly alarmed at the substantial minimum mining requirements and annual escalation in the royalty, suggesting that the only plausible justification for such overcompensation would be an anticompetitive intent to foreclose the ore properties from 
competitors. ${ }^{118}$ This mechanism, however, has a benign justification of providing optimal incentives to both parties. For example, US Steel's "take or pay" commitment to mine an annual minimum tonnage of ore ensured US Steel would fulfill its obligations to develop the land. ${ }^{119}$

Consider how the "take or pay" obligation affected US Steel's incentives in the execution of the lease, and how that in turn affected the Great Northern's incentives. Ex-post, US Steel's marginal acquisition cost of ore up to the "take" quantity is zero, since the royalty payment is sunk at that point. ${ }^{120}$ So US Steel has an incentive to undertake investments to develop the ore land and actually take delivery of ore that it has already paid for. The Great Northern Railway, on the other hand, knows that it can undertake specific investments to accommodate this anticipated ore traffic, since even if this ore traffic does not materialize, US Steel is still obligated to pay for at least some of the specific costs the Railway has incurred.

US Steel would have the incentive to prepare for substantial mining over the course of years, abandoning their sunk investment only if their resources could be put to better use at another site. ${ }^{121}$ From prior experience, US Steel recognized annual minimums committed them to make significant investments in their mines so that it could produce enough tonnage to satisfy its contractual obligations. ${ }^{122}$ This prediction was confirmed over the course of the many take or pay contracts US Steel had executed. As a result of such contracts, even during periods of industry-wide contraction, US Steel continued its Mesabi operations. ${ }^{123}$ This commitment to exploit the acquired property is directly contrary to the foreclosure hypothesis, which would predict that US Steel would simply stockpile unexploited ore reserves. 


\subsubsection{Royalty Rate}

The Bureau of Corporations considered the 85 cent royalty for the Hill ore lands to be "absolutely unprecedented."124 Some other numbers serve as a basis for comparison. From 1902-1906, the average royalty on all Mesabi ore was 26 cents per gross ton, as reported by the Bureau of Corporations. ${ }^{125}$ The Bureau also reported other components entering into the cost of ore delivered at lower lake ports. The average book cost per ton at mine, including the royalty, was 78 cents for Mesabi range ores. Rail freight from the mine to Superior, Wisconsin, or some other appropriate port averaged 80 cents. Lake freight from Superior to a lower lake port such as Cleveland averaged 77 cents. With the addition of taxes and general expenses, the total book cost of Mesabi ore at a lower lake port averaged $\$ 2.45 .{ }^{126}$ Strikingly, this was below the book cost of ores from other ranges in the Lake Superior region: $\$ 2.62, \$ 2.93$ and $\$ 3.09$ for the Marquette, Menominee, and Gogebic range ores, respectively. ${ }^{127}$ The extraction costs on the Mesabi were lower, and this was only partially offset by the higher transportation costs. Moreover, these total book costs were below the prices delivered ore commanded. The base price for delivery at lower Lake Erie ports in 1906 was $\$ 4.00$ for Mesabi Bessemer and $\$ 3.50$ for Mesabi non-Bessemer. ${ }^{128}$ So although an 85 cent royalty was very large, it could still be paid profitably if the lease enabled the Mesabi to be exploited on a larger and lower cost scale.

Note that the royalty was specified in terms of a nominal dollar amount per ton, rather than on a percentage basis. This appears to have been a common feature of contemporary iron ore leases, and so this aspect of the Hill lease did not receive considerable attention. ${ }^{129}$ One may speculate on the reasons for this arrangement. The alternative of specifying a royalty based on a "market price" at the point of ore production would have been untenable, because that market was very 
thin. Ore from the Lake Superior region, which included the Mesabi range, was "sold chiefly at the lower Lake ports, hundreds of miles from the place of production."130 Perhaps US Steel could have had undue influence on the market price for such ore, since even before the Hill deal it mined 56 percent of the total Lake Superior ore production. ${ }^{131}$ Furthermore, there may have been scope for manipulating a market price by the railroad precisely because transportation was required for the ore to reach the relevant market.

The royalty rate of 85 cents per gross ton was due to rise by 3.4 cents per year, which represented a 4 percent annual increase in the royalty rate. Such a provision was probably not designed to account for expected economy-wide inflation, since prices had recently stabilized after decades of deflation. The stipulated 4 percent interest on ore in the ground further encouraged US Steel to frontload its investment and extraction efforts. ${ }^{132}$

Assuming that US Steel was paying an "above market" rate for the Hill ore, why was the lease structured to require US Steel to pay a royalty rate above the opportunity cost of the ore? Such a wedge could generate distortions in behavior ex-post, and therefore lower the total value of the transaction to both parties. One possibility is connected with the take or pay provision. Since the payments due on the take level were sunk, US Steel's ex-post marginal acquisition cost went from zero (up to the take level) to the 85 cent royalty rate, which included a premium for the Great Northern. Thus if US Steel subsequently decided to mine and deliver ore in excess of the take level, it would have to compensate the Great Northern ex-post on this margin. This additional compensation might reflect a capacity constraint on the Great Northern, even beyond the expansion of facilities that would be involved in executing other elements of the lease.

Support for this interpretation comes from another lease term. The Great Northern Railway was required "to furnish adequate equipments and facilities for receiving, transporting, and docking 
all the ores to be mined by the lessee." This requirement had the following proviso. The lessors, the Great Northern, would not be required to furnish "tracks or facilities in any year for transporting or delivering a greater tonnage than the minimum herein fixed for such year, except upon reasonable notice in writing first given by the lessee to the trustees." 133 The requirement of advance notice suggests the need to expand transportation capacity even further for ore levels beyond that year's take level.

There is no indication of a maximum quantity specified in the lease, although perhaps because the guaranteed minimums were so substantial, they were thought to be effective maximums, so that once US Steel put its mining operation fully into place, it was anticipated that there would be only relatively small year to year fluctuations in deliveries around the take level.

\subsubsection{Freight rate}

The royalty rate was not the only consideration the Great Northern received. Ore was to be transported exclusively on the Great Northern at the rate of 80 cents per ton. The freight of 80 cents was the current market rate for Mesabi transport, but the estimated cost of transporting such ore was approximately 30 cents per ton, with costs expected to decline further over the duration of the lease. ${ }^{134}$ This seemingly excessive freight charge promised the Great Northern may have a procompetitive justification serving as a "performance bond." One available mechanism to prevent opportunistic behavior is to offer the potential opportunist a future premium, a price sufficiently

over spot market to assure income that would exceed the benefits of opportunistic renegotiation. ${ }^{135}$ In the present case, the freight charges can be understood as a variable premium which tied the interests of the contracting parties together throughout the life of the contract.

In fact, the need for a performance bond was magnified by another contractual term. The take 
or pay provision might have encouraged opportunism by the Great Northern. Why should the railroad incur the costs of expanding its facilities? After all, although such a decision would reduce the tonnage mined, US Steel was still obligated to pay for the annual minimum. Significantly, the take or pay provision applied only to the royalty rate on ore, not to the freight rate. ${ }^{136}$ Furthermore, the lease provided that if the Great Northern did not furnish the necessary tracks, equipment, and facilities, then after reasonable notice, the Great Northern would be placed in default on the lease, and US Steel would be allowed to make other transportation arrangements for the period of the default. So the freight rate may have played an important role in assuring Great Northern's performance.

These provisions also illustrate the mutually reinforcing features of the lease, carefully aligning and balancing both sets of interests to facilitate optimal ex-post execution by both parties.

Of course, if the stipulated freight rate was above the marginal cost of transportation, it could lower the value of the transaction by inducing distorted choices e-post. For example, one might wonder about US Steel's decision to build a steel plant in Duluth, Minnesota. Since Duluth is on Lake Superior, the plant was designed to receive ore after it had been transported by the Great Northern from the Mesabi range. Since alternative steel production was located in Gary or Pittsburgh, the Duluth plant was sited to save on the cost of transporting ore to these alternate locations. The Duluth plant was planned to produce steel for markets west and north of the Great Lakes. ${ }^{137}$ Because the transportation cost savings that motivated the Duluth plant largely involved Lake freight and railroads other than the Great Northern, it is unlikely that the lease's 80 cent freight rate played a significant role in this investment decision. 


\subsubsection{Sliding Scale Royalty}

One lease term which has been largely overlooked is the sliding scale of royalty prices for the mining of ore of lower grade. This pricing structure encouraged US Steel to internalize the gains on exploitation of an additional synergy resulting from combining the Great Northern Properties with US Steel's preexisting Mesabi holdings. Although the Mesabi ore was known to be of generally high quality, a substantial portion of the range was of lesser grade. During the years leading up to and immediately following the Hill Ore Lease, US Steel worked on perfecting devices for concentrating the immense quantity of sandy ores on the Western Mesabi Range. ${ }^{138}$

Following two years of intensive experimentation, US Steel made a significant site specific investment in 1908 as it erected a permanent washery and concentrating plant on the Western Mesabi, at Coleraine, Minnesota, at a total cost of $\$ 1.4$ million. ${ }^{139}$ US Steel anticipated that the concentrating plant would process ore with an iron content as low as 36 percent, producing concentrated ore with iron content in the neighborhood of 57 percent. ${ }^{140}$ By 1911, the plant was operating near its full capacity. ${ }^{141}$ The sliding scale feature of the lease made the lean ores a relative bargain for US Steel $^{142}$ which could therefore internalize the gains resulting from its investments in concentrating technology, plants, and equipment. US Steel ultimately failed to realize the maximum benefit from the sliding scale, however, because it terminated the lease prior to the time when it could extract a substantial tonnage of low grade ore from the Great Northern Properties. ${ }^{143}$

\subsubsection{Unilateral Option to Terminate}

These apparent efficiency benefits from the lease raise the question of why, if the lease were so clearly beneficial, did US Steel insist upon receiving an option to cancel the lease in 1915 . One possible explanation is that the uncertainty involved in the ore acquistion in 1906 was so substantial that 
prudence dictated reevaluation of the economics of the transaction prior to committing to meet the annual minimum of 8.25 million tons for the duration of the lease. In addition to this business factor, there is an additional potential efficiency concern. The principal difficulty posed by uncertainty in the presence of relationship-specific investment is that contractual gaps tend to be larger and the occasions for sequential adaptations (and thus for opportunistic behavior) increase concurrently with the increase in uncertainty.

Uncertainty clearly was a significant factor in US Steel's evaluation of the Hill Ore Lease in 1906. The parties had to make rough estimates of the magnitude and quality of the ore holdings, estimates that varied dramatically. ${ }^{144}$ In addition, the value of the lease over time would depend on the relative scarcity of available iron ore both domestically and internationally. ${ }^{145}$ Finally, future demand by US Steel and the steel industry as a whole could not be precisely predicted. The unilateral option to terminate the relationship is an easily enforceable feature which could foster efficient adaptation as these uncertainties were resolved over time. ${ }^{146}$ It is difficult to assess the efficacy of the lease cancellation option as an enforcement mechanism, however, both because the mechanism would likely be exercised privately and because the threat of the government's dissolution suit prompted US Steel to cancel the lease prematurely before it could serve its intended business purpose.

The lease did not give the Great Northern Railway a similar option to terminate its obligations. The benefits from such an option would have been relatively low, since as indicated most of the uncertainty about the value of the lease was on the side of US Steel. Moreover, the costs of adding such an option could have been substantial. If both parties to an exchange have the option to terminate the arrangement, then such an option can be used as a threat to renegotiate terms opportunistically ex-post. Ex-post bargaining, and its attendant threat to relationship-specific 
investments, would have been encouraged. Of course, US Steel might have used its sole possession of this option to extract rents from the Great Northern ex-post, but the Great Northern's position was protected by other lease terms, in particular the take or pay requirement.

Because US Steel did exercise its option to terminate, we can examine the implementation of that option. In particular, was there a "settling up" of specific investments by the parties before control was surrendered? We have been unable to find what lease terms governed the settling up of specific investments. We know a little bit more about how settling up occurred.

US Steel permitted the Trustees to begin preparing mines which US Steel did not plan to work prior to 1915 . In return for permission to begin developing the properties, the certificate holders agreed to assume payment of taxes on such properties, which were turned over on March $1,1912 .{ }^{147}$

At the termination of the lease on December 31, 1914, the Trustees for the Great Northern Ore properties took possession of all eight mines that had been developed by US Steel. Five of those mines had been nearly exhausted, but three contained considerable unexploited tonnage. In 1914 "the railway tracks, head frames, boiler and engine houses, and considerable other equipment of [these] mines, were purchased, in place" from the Steel Corporation by the Trustees. ${ }^{148}$ The purchase price for these assets was not disclosed in the annual reports of either the Trustees or the Steel Corporation. ${ }^{149}$ There is no indication that US Steel made any additional payments to the Great Northern Railway to cover the Railway's investments. This is unsurprising, since the high take or pay requirements served in part as payment for those investments. Moreover, since the lease termination resulted in the ore lands reverting to the Great Northern's control, the Railroad was better positioned than US Steel to recoup its investments after the lease period. 


\subsubsection{Lease vs. Sale}

We examine one other lease "term," namely the lease structure itself. The parties decided to structure the transaction as a lease rather than as a sale of the Great Northern Properties. This is striking, since much of the transaction cost literature emphasizes the potential for opportunism in the execution of long term contracts. The choice of a lease structure may have been a concession to the economic reality that the Great Northern was not the fee owner of all the properties. ${ }^{150}$ Yet there are suggestions that a lease arrangement might have been preferred to an ownership relationship. As modelled by Grossman and Hart (1986), ownership is the acquisition of residual rights of control. The acquisition of these rights by one party deprives those rights from the second party, and this can adversely affect the second party's incentives to undertake investments. The lease structure was chosen to establish the comparative duties of the parties, both of whom were important to the success of the venture. As we have noted, both US Steel and the Great Northern had to make investments in executing the lease. Thus, even if sale in fee of the Great Northern Properties had been possible, the need to preserve incentives ex post for both parties may have made a long-term contracting structure preferable. ${ }^{151}$

The problems with an outright ownership arrangement can be illustrated by considering what would have happened had US Steel purchased the Great Northern Ore lands directly. It then would have needed to contract with the Great Northern railroad (or some other railway) for freight services. Although railroad freight rates were regulated in this period, there is potential for ex-post opportunism by both parties. If US Steel attempted to negotiate a freight agreement after it had sunk investments on the land, part of the value of this investment could be expropriated ex-post by the Great Northern. On the other hand, once the Great Northern sunk the required expansion of 
track and loading docks to handle the expanded ore traffic, those site specific assets were not going to be moved. Hence, US Steel could then attempt to renegotiate more favorable freight terms. The problems of bilateral monopoly emphasized in the transaction cost literature loom large.

Nevertheless, it is reasonable to inquire whether the problem is created by the governance structure (ownership versus lease), or whether it is created by the sequential rather than simultaneous timing of agreements. One might imagine that a sale agreement could include a clause indicating that ore would be carried on the Great Northern Railway at pre-specified terms. Such a clause, if enforceable ex-post, could constrain both parties' ex-post bargaining flexibility and hence reduce opportunistic behavior. Clearly, some of the lease terms could have been replicated, for example agreeing to high freight charges to serve as a performance bond for the Great Northern. But other features seem unique to the lease arrangement. For example, US Steel's unilateral option to terminate gave it both flexibility to adapt to changed external circumstances and a threat to use against non-performance by the Great Northern.

\subsection{Are lease terms consistent with vertical foreclosure?}

Although the foregoing has outlined the efficiency rationale for these various lease terms, it is worthwhile to step back and consider which terms were or were not compatible with the alternate hypothesis of vertical foreclosure. In particular, if bringing the Great Northern ore lands under the control of US Steel would generate vertical foreclosure, then that would create private value for the contracting parties. That private value would be from the monopoly profits created or defended by this lease, and so one might expect that the lease would share these monopoly rents with the Great Northern Railway.

Although not couched precisely in that language, that is clearly the intuition underlying the 
Bureau of Corporation's condemnation of the high royalty and freight rates the Great Northern interests were to receive in the lease. The Great Northern's profitable arrangement was taken as evidence of anticompetitive effect. The presence of profits or a premium for the Great Northern is consistent with vertical foreclosure; the precise form of this arrangement is more difficult to reconcile with the foreclosure hypothesis. In particular, why was the Great Northern compensated based on royalties and freight rates, in other words, based upon the quantity of ore extracted from the property? As an alternative arrangement, US Steel could have bought the Great Northern lands outright, or at least all those lands held in fee by the Great Northern. If a lease arrangement was necessary, US Steel could have contracted to lease the land for a fixed charge per year, or an increasing charge over time.

The one advantage of the royalty arrangement was in sharing risk between the parties concerning the total amount of ore in the Great Northern lands. Because this was unknown to both parties, a royalty rate would provide better insurance than a fixed annual charge. For example, if the ore on the Hill properties turned out to be unexpectedly low, US Steel's royalty and freight payments would fall. But from a foreclosure perspective, this was very expensive insurance, since under foreclosure the value of the transaction comes from keeping the ore out of production. So the actual lease, by generating incentives for the properties to be exploited ex-post, directly undermined any foreclosure motivation.

This is related to another point that has been raised earlier. The take or pay provision, by inducing US Steel to exploit the properties ex-post, is directly contrary to the foreclosure hypothesis, which would have left these ores unexploited. Of course, hypothetically US Steel could have reduced its exploitation of its other ore lands to more than offset its exploitation of the Great Northern properties. But the historical record suggests otherwise. First, because US Steel had sizeable 
annual minimums on its other ore leases, it was committed to exploit those properties as well. Second, US Steel's total iron ore production rose in the aftermath of the Hill lease, increasing from $18,486,556$ tons in 1905 to $25,245,816$ tons in $1910 .^{152}$

US Steel's unilateral option to terminate the lease is problematic for some models of vertical foreclosure but not for others. In the early work on foreclosure, up through models by Krattenmaker and Salop (1986) and Ordover, Saloner, and Salop (1990), successful foreclosure requires that the integrated firm commit not to supply its unintegrated rivals with the input, or alternatively, that the integrated firm commit not to supply its unintegrated rivals except at a very high price. An option to terminate the vertical relationship is the opposite of a commitment, since it preserves some flexibility. This is not a problem for the Hart and Tirole (1990) model, since they derive foreclosure effects from profit sharing within the integrated firm rather than from commitment.

Nevertheless, the cancellation option, when coupled with the other terms of the lease, poses a problem under any of these theories of foreclosure. Because the other lease terms committed US Steel to develop the properties, if they surrendered these properties they would leave rivals with enhanced access to iron ore. That possibility was recognized by Iron Age in $1907,{ }^{153}$ and subsequent experience bore out that concern. Strikingly, the leases made by the Trustees immediately following US Steel's cancellation of the Hill Ore Lease involved those mines which had been previously developed either by US Steel or the Trustees. ${ }^{154}$ Admittedly, US Steel cancelled the lease under antitrust pressure. But whatever the motive, cancellation after investments were sunk would bring about an outcome opposite of foreclosure. 


\section{Conclusion}

The quantitative and qualitative evidence presented in this paper supports the hypothesis that the Hill Ore Lease was an efficient governance structure designed to overcome the problem of ex post opportunism that typically arises in contracts involving significant relationship-specific investment. Conversely, the evidence seriously undermines the conventional foreclosure explanation of US Steel's acquisition of the Great Northern Properties, a view which has enjoyed widespread acceptance.

Beyond the historical significance of these findings, the data has shown that US Steel, a firm with greater than 50 percent of the market share in both the iron ore and steel markets, acquired the final significant independent source of iron ore, and yet generated a positive efficiency sufficient to generate an implied lowering of steel prices. This astonishing result forces serious reconsideration of the advisability of the recent attention directed at vertical relationships among firms with much lower levels of market share and industry concentration. 


\section{References}

[1] Allen, Bruce T. "Vertical Integration and Market Foreclosure: The Case of Cement and Concrete." Journal of Law and Economics 14 (1971).

[2] Arquit, Kevin J. "Developments and Trends in FTC Antitrust Enforcement." 35th Annual Antitrust Law Institute. Practicing Law Institute, 1994.

[3] Bolton, Patrick and M.D. Whinston. "The 'Foreclosure' Effects of Vertical Mergers." Journal of Institutional and Theoretical Economics 147 (1991) 207-226.

[4] Bolton, Patrick and M.D. Whinston. "Incomplete Contracts, Vertical Integration, and Supply Assurance." Review of Economic Studies 60 (1993) 121-148.

[5] Bork, Robert. The Antitrust Paradox. New York: The Free Press, 1993.

[6] "Capitalization of United States Corporations and Securities Listed on the Stock Exchange." Commercial and Financial Chronicle. January 16, 1915.

[7] Chipty, Tasneem. "Vertical Integration, Market Foreclosure, and Consumer Welfare: An Empirical Investigation." Mimeo (1995).

[8] Coase, Ronald. "The Nature of the Firm." Economica n.s. 4 (1937) 386-405.

[9] Coase, Ronald H. The Firm, the Market, and the Law. Chicago: University of Chicago Press, 1988.

[10] Cotter, Arundel. The Authentic History of the United States Steel Corporation. New York: Moody Magazine and Book Company, 1916.

[11] Crocker, Keith J. and Masten, Scott E. "Mitigating Contractual Hazards: Unilateral Options and Contract Length." Rand Journal of Economics 16 (1988).

[12] Dyckman, Thomas, Philbrick, Donna, and Stephan, Jens. "A Comparison of Event Study Methodologies Using Daily Stock Returns: A Simulation Approach." Journal of Accounting Research 22, Supplement (1984) 1-30.

[13] Eckbo, B.E. "Horizontal Mergers, Collusion, and Stockholder Wealth." Journal of Financial Economics 11 (1983).

[14] Ellison S.F. and W.P. Mullin. "Economics and Politics: The Case of Sugar Tariff Reform." Journal of Law and Economics 38 (1995) 335-366.

[15] Fox, Eleanor M., Silberman, Alan H., Proger, Philip A., and Weinbaum, Robert C. "Report from Officialdom: 60 Minutes with Anne K. Bingaman, Assistant Attorney General, Antitrust Division, US Department of Justice." Antitrust Law Journal 63 (Fall 1994).

[16] Great Northern Iron Ore Properties, Annual Report of the Trustees for the Periods Ended 1906-1917. 
[17] Grimm, Curtis, Winston, Clifford, and Evans, Carol. "Foreclosure of Railroad Markets: A Test of Chicago Leverage Theory." Journal of Law and Economics 35 (1992).

[18] Grossman, Sanford J. and Hart, Oliver D. "The Costs and Benefits of Ownership: A Theory of Vertical and Lateral Integration." Journal of Political Economy 94:4 (1986).

[19] Hart, Oliver and Tirole, Jean. "Vertical Integration and Market Foreclosure." Brookings Paper: Microeconomics (1990).

[20] Hart, Oliver. Firms, Contracts, and Financial Structure. Oxford: Clarendon Press, 1995.

[21] Hogan, William T. Economic History of the Iron and Steel Industry in the United States. Lexington: Lexington Books, 1971.

[22] Joskow, Paul L. "Vertical Integration and Long-term Contracts: The Case of Coal-burning Electric Generating Plants." Journal of Law, Economics, and Organization I (1985).

[23] Joskow, Paul L. "Asset Specificity and the Structure of Vertical Relationships: Empirical Evidence." Journal of Law, Economics, and Organization IV (1988).

[24] Joskow, Paul L. "Contract Duration and Relationship-Specific Investment: Empirical Evidence from Coal Markets." The American Economic Review 77:1 (March 1987).

[25] Kessler, Friedrich and Stern, Richard H. "Competition, Contract, and Vertical Integration." Yale Law Journal 69 (1959).

[26] Klein, Benjamin, Crawford, Robert G. and Alchian, Armen A. "Vertical Integration, Appropriable Rents, and the Competitive Contracting Process." The Journal of Law and Economics 21 (1978).

[27] Krattenmaker, Thomas and Salop, Steven. "Anticompetitive Exclusion: Raising Rivals' Costs to Achieve Power Over Price." Yale Law Journal 96 (December 1986).

[28] Lopatka, John E. and Godek, Paul E. "Another Look at Alcoa: Raising Rivals' Costs Does Not Improve the View." Journal of Law and Economics 35 (1992).

[29] Masten, Scott E. and Crocker, Keith J. "Efficient Adaptation in Long-Term Contracts: Take or Pay Provisions for Natural Gas." American Economic Review 75 (December 1985).

[30] Masten, Scott E. "Minimum Bill Contracts: Theory and Policy." Journal of Industrial Economics 37 (1988) 85-97.

[31] Moody, John Moody's Analyses of Investments: Steam Railroads. New York: Analyses Publishing Company, 1925.

[32] Mullin, George L., Mullin, Joseph C. and Mullin, Wallace P. "The Competitive Effects of Mergers: Stock Market Evidence from the U.S. Steel Dissolution Suit." Rand Journal of Economics 26:2 (Summer 1995).

[33] Mullin, George L., Mullin, Joseph C., and Mullin, Wallace P. "The Dominant Firm Hypothesis, the Puppy Dog Ploy, and Competitive Effects of Mergers: Stock Market Evidence From the US Steel Dissolution Suit." July 1993. 
[34] Ordover, Janusz A. Saloner, Garth, and Salop, Steven C. "Equilibrium Vertical Foreclosure." American Economic Review 80 (1990).

[35] Parsons, Donald O. and Ray, Edward John. "The United States Steel Consolidation: The Creation of Market Control." Journal of Law and Economics 18 (April 1975).

[36] Perry, Martin K. "Vertical Integration: Determinants and Effects." Handbook of Industrial Organization.Schmalensee, Richard and Willig, Robert D., eds. New York: North Holland, 1989.

[37] Posner, Richard A. and Easterbrook, Frank H. Antitrust Cases, Economic Notes and Other Materials. St Paul: West, 1981.

[38] Report of the Commissioner of Corporations on the Steel Industry. Part I: Organization, Investment, Profits, and Position of United States Steel Corporation, July 1, 1911.

[39] Report of the Commissioner of Corporations on the Steel Industry. Part III: Cost of Production, Full Report, May 6, 1913.

[40] Report of the Federal Trade Commission on the Control of Iron Ore for the Antitrust Subcommittee of the Committee on the Judiciary of the House of Representatives, December 24, 1952.

[41] Royston, J.P. "Approximating the Shapiro-Wilk W-test for non-normality." Statistics and Computing 2 (1992).

[42] Rubinstein, Ariel. "Perfect Equilibrium in a Bargaining Model." Econometrica 50 (1982) 97109.

[43] Salinger, Michael A. "Vertical Mergers and Market Foreclosure." Quarterly Journal of Economics (May 1988).

[44] Scherer, F.M. Industrial Market Structure and Economic Performance. Chicago: Rand McNally \& Co., 1970.

[45] Shapiro, S.S. and M.B. Wilk. "An Analysis of Variance test for normality (complete samples)." Biometrika 52 (1965) 591-611.

[46] Snyder, Christopher. "Interfirm Effects of Vertical Integration: Event Studies of the U.S. Oil Industry." George Washington University Mimeo (1995)

[47] Snyder, Christopher. "Vertical Foreclosure in the British Beer Industry." George Washington University Mimeo (1995)

[48] Stigler, George J. "Mergers and Preventative Antitrust Policy." University of Pennsylvania Law Review 104 (1955).

[49] Stillman, R. "Examining Antitrust Policy Toward Horizontal Mergers." Journal of Financial Economics 11 (1983). 
[50] Stuckey, John A. Vertical Integration and Joint Ventures in the Aluminum Industry. Cambridge: Harvard University Press, 1983.

[51] Sweeney, "Vertical Mergers: Competitive and Efficiency Effects." Economic Analysis and Antitrust Law. Terry Calvani and John Siegfried, eds. Boston: Little Brown and Company, 1988.

[52] US Government Brief. United States vs. United States Steel. Filed 1912 in the Federal District Court of New Jersey.

[53] United States v. E.I. Du Pont De Nemours and Co., 353 U.S. 586 (1957).

[54] United States v. United State Steel Corporation, 223 F. 55 (D. NJ 1915), aff'd 251 U.S. 417 (1920).

[55] The United States Steel Corporation's Annual Report. 1902-1918.

[56] United States House of Representatives, Hearings Before the Committee on Investigation of the United States Steel Corporation, 1911-1912

[57] Williamson, Oliver E. Markets and Hierarchies: Analysis and Antitrust Implications. New York: Free Press, 1975.

[58] Williamson, Oliver E. "Transaction-Cost Economics: The Governance of Contractual Relations." The Journal of Law and Economics 22 (1979).

[59] Williamson, Oliver E. "Credible Commitments: Using Hostages to Support Exchange." American Economic Review 73 (1983).

[60] Williamson, Oliver E. "Transaction Cost Economics." Handbook of Industrial Organization. Schmalensee, Richard and Willig, Robert D., eds. New York: North Holland, 1989. 


\section{Notes}

${ }^{1}$ Ronald H. Coase, The Firm, the Market, and the Law, (Chicago: University of Chicago Press, 1988), 63-67.

${ }^{2}$ James J. Hill was President, founder, and principal stockholder of the Great Northern Railway. His entrepreneurial efforts were primarily responsible for the acquisition of the Great Northern Properties. Dwight E. Woodbridge, "The Hill Iron Ore Properties," The Iron Age, January 4, $1906,26-28$.

${ }^{3}$ The editors of the industry trade journal, The Iron Age, considered the ore situation to be an example of "competitive pre-emption of mineral resources for use in the distant future." "The Pre-emption of Mineral Reserves," The Iron Age, October 4, 1906, 876; "The Question of Capitalization," The Iron Age, August 9, 1906, 355 (Chief requisites for entry are "adequate raw supplies and practically unlimited capital.").

${ }^{4}$ US Steel and its ore acquisitions were closely scrutinized by the Bureau of Corporations in its Report on the steel industry, by the House of Representatives in the Stanley Committee Hearings, and ultimately by the courts in the Department of Justice's dissolution suit filed in 1911.

${ }^{5}$ Donald O. Parsons and Edward John Ray, "The United States Steel Consolidation: The Creation of Market Control," Journal of Law and Economics 18 (April 1975): 184.

${ }^{6}$ Estimates of US Steel's percentage of domestic iron ore holdings following the execution of the Hill Ore Lease varied between a high of 85 percent of total stocks to a conservative estimate of 38.5 percent of the available, desirable ores. "The Iron Reserves of the United States," The Iron Age, June 24, 1909, 2014. 
${ }^{7}$ During this period, US Steel's share of the steel market fluctuated between 50 and 60 percent. F.M. Scherer, Industrial Market Structure and Economic Performance (Chicago: Rand McNally \& Co., 1970), 457 .

${ }^{8}$ Dwight E. Woodbridge, "The Lake Iron Trade in 1906," The Iron Age, January 3, 1907, 60.

${ }^{9}$ As to the lands owned in fee by the Great Northern, the lease was to run until the mines were exhausted of ore with an iron content of 49 percent or more. US Steel could then continue the lease at its option. As to the leasehold properties, the term of the subleases was three months shorter the term of the original leases. Report of the Commissioner of Corporations on the Steel Industry, Part I: Organization, Investment, Profits, and Position of United States Steel Corporation, July 1, $1911,262$.

${ }^{10}$ US Steel was the nation's leading industrial corporation. On the other side of the transaction was industrialist and railroad developer James Hill, one of the nation's wealthiest individuals. "Hill Prefers Credit to Cash," The New York Times, October 7, 1906, 1.

${ }^{11}$ One indication of the significance of the contract is its enormous length, running in excess of 1000 printed pages. "The Great Northern Iron Ore Lease," The Iron Age, October 19, 1911, 854.

${ }^{12}$ The form of lease was available for inspection by the stockholders. The United States Steel Corporation, Seventh Annual Report for the Year Ended December 31, 1906, 28.

${ }^{13}$ It was thought that the royalty charged in the Hill Ore Lease would have a significant effect both on accounting revaluations of ore holdings and the terms of some future Mesabi transactions. Woodbridge, "The Lake Iron Trade in 1906," 60. 
${ }^{14}$ Parsons and Ray, "US Steel Consolidation," 198.

${ }^{15}$ The majority of both of these companies' holdings were on the Western Mesabi in Minnesota on the coast of Lake Superior with the Great Northern Properties amounting to approximately 39,300 acres. Dwight E. Woodbridge, "The Western Mesaba Iron Range," The Iron Age, February 1, 1906, 420 .

${ }^{16}$ Throughout the remainder of the paper, we will refer to US Steel's wholly owned subsidiaries as US Steel. In particular, this will include the Oliver Mining Company which was responsible for the bulk of US Steel's mining operations on the Mesabi, and the Great Western Mining Company which assumed the performance obligations of US Steel under the Hill Ore Lease, guaranteed by US Steel. US Steel Annual Report for 1906, 28.

${ }^{17}$ Dwight E. Woodbridge, "The Hill Iron Ore Properties," The Iron Age, January 4, 1906, 26. In 1906, the Wall Street Journal reported that the Great Northern had Mesabi ore holdings of $500,000,000$ tons in the ground, US Steel had 600,000,000 tons, and all the other interests combined had 200,000,000 tons. Industry observers, however, discounted such estimates because of the lack of definitive exploration of the Mesabi. "The Exact Quantity of Ore in the Hill Properties," The Iron Age, January 18, 1906, 280.

18 "Handling Material on the Mesaba," The Iron Age, March 15, 1906, 963.

${ }^{19}$ Woodbridge, "Western Mesaba," 421.

20 "Ore Transport Hampered," The Iron Age, August 2, 1906, 305.

21 "Ore Shipments Below Expectations," The Iron Age, August 30, 1906, 564. "The Marvel of 
the Lake Trade," The Iron Age, September 13, 1906, 678 (Lack of dock and railroad facilities have slowed movement of the ore trade.).

${ }^{22}$ Report of the Commissioner, Part I, 260.

23“The Great Northern Ore Output," The Iron Age, March 26, 1908, 1012.

${ }^{24}$ The standard rate was based on 59 percent iron content. The royalty was to be reduced 4.82 cents for each percentage point drop in iron content below 59 percent. For ore with an iron content below 48 percent, the price adjustment was subject to negotiation and arbitration. "The Great Northern Iron Ore Lease," The Iron Age, October 19, 1911, 854. The report of this final term conflicts with the Bureau of Corporation's account of the lease in which ore below 49 percent iron content was subject to a total consideration of $\$ 1.10$ (30 cents royalty plus 80 cents freight). Report of the Commissioner, Part I, 262. The issue of how best to adjust for deviations in iron content was significant at the time with various contractual remedies attempted. "A New Penalty and Bonus Provision in Iron Ore Contracts," The Iron Age, July 16, 1908, 202.

${ }^{25}$ The freight of 80 cents was the current market rate for Mesabi transport, but the estimated cost of transporting such ore was approximately 30 cents per ton, with costs expected to decline further over the duration of the lease. "The Hill Ore Properties Leased," The Iron Age, October $11,1906,953$.

${ }^{26}$ Masten and Crocker define "take or pay" provisions as terms that require "purchasers to pay for a contractually specified minimum quantity of output, even if delivery is not taken." Scott E. Masten and Keith J. Crocker, "Efficient Adaptation in Long-term Contracts: Take-or-Pay Provisions for Natural Gas," The American Economic Review 75 (December 1985): 1083. 
27 "The Hill Ore Properties Leased," The Iron Age, October 11, 1906, 953.

${ }^{28}$ There were only two developed mines in operation at the time the lease was signed. "The Hill Ore Properties Leased," The Iron Age, October 11, 1906, 953.

${ }^{29}$ Any deficit in mining the guaranteed minimums was to be prepaid as to the ore, but not as to the freight. Credit for the prepayment was carried over year to year so that US Steel did not forfeit any royalty payments. "Great Northern Ore Land Earnings," The Iron Age, December 6, 1906, 1515; "The Great Northern Iron Ore Lease," The Iron Age, October 19, 1911, 855.

${ }^{30}$ United States House of Representatives, Hearings Before the Committee on Investigation of the United States Steel Corporation, No. 52 (February 28, 1912), 3462. Bureau of Corporations, Report of the Commissioner, Part I, 225.

31 "The Hill Ore Lease," The Iron Age, March 28, 1907, 986.

${ }^{32}$ Report of the Commissioner, Part I, 377.

33 "The Cancellation of the Hill Ore Lease," The Iron Age, October 26, 1911, 884.

${ }^{34}$ Parsons and Ray, "US Steel Consolidation," 216.

35 "The Cancellation of the Hill Ore Lease," The Iron Age, October 26, 1911, 884.

${ }^{36}$ United States v. United State Steel Corporation, 223 F. 55 (D. NJ 1915), aff'd 251 U.S. 417 (1920). The court held that in view of the availability of alternative sources of ore and "of the fact that the option to cancel the ore lease...had been exercised when the present petition was filed, it would seem that the ore reserve of the Steel Corporation held at that time gave it no monopoly in ore." US Steel, 223 F. at 147. 
${ }^{37} 251$ U.S. 417 (1920). The Supreme Court did not consider the Hill Ore Lease.

38 "The Cancellation of the Hill Ore Lease," Iron Age, October 26, 1911 p. 884-885.

${ }^{39}$ For a critical review of this theory and its application to the Alcoa case, see John E. Lopatka and Paul E. Godek, "Another Look at Alcoa: Raising Rivals' Costs Does Not Improve the View," Journal of Law and Economics 35 (1992): 311-329.

${ }^{40}$ Bolton and Whinston (1991) advance a common, simple framework encompassing their (1993) model and the Hart and Tirole (1990) model in order to clarify comparisons of these models.

Patrick Bolton and M.D. Whinston, "The 'Foreclosure' Effects of Vertical Mergers," Journal of Institutional and Theoretical Economics 147 (1991): 207.

Patrick Bolton and M.D. Whinston, "Incomplete Contracts, Vertical Integration, and Supply Assurance," Review of Economic Studies 60 (1993): 121.

${ }^{41}$ This assumption on the contracting process varies in other variants of their model that we do not discuss.

${ }^{42}$ In the equilibrium under non-integration, $U_{1}$ supplies both $D_{1}$ and $D_{2}$ with the Cournot quantity corresponding to $c_{1}$.

${ }^{43}$ The authors argue that profit sharing cannot be accomplished under non-integration.

${ }^{44}$ In particular, if $c_{2}$ is infinite, so that $U_{1}$ is a monopolist, then under integration $U_{1}$ will supply the monopoly output to $D_{1}$ and sell nothing to $D_{2}$. If $c_{2}$ is finite, but still larger than $c_{1}$, then under integration $U_{1}$ will supply $D_{2}$ with the quantity that $U_{2}$ would supply, but at a slightly lower price. 
An alternative contractual arrangement that might accomplish the same end as vertical integration would be exclusive dealing. Hart and Tirole argue that exclusive dealing may not be enforceable without integration, and moreover that it would not be optimal in certain circumstances.

${ }^{45}$ As pointed out by Hart and Tirole, the model of Ordover, Salop, and Saloner (1990) can be considered as essentially a special case of the variant discussed here, except with identical upstream firms $\left(c_{1}=c_{2}\right)$. One weakness of the Ordover, Saloner, and Salop model is that they assume that vertical integration enables $U_{1}-D_{1}$ to commit not to supply $D_{2}$ below some price $\bar{p}$ chosen by the merged entity. In equilibrium, this commitment raises $D_{2}$ 's marginal cost, and thereby creates profits for $U_{1}-D_{1}$ and the incentive for vertical integration. This commitment is not credible, however. In the Hart and Tirole model, under vertical integration there is no need for such an ex ante commitment since profit sharing ensures that $U_{1}-D_{1}$ will not "oversupply" $D_{2}$ ex post.

${ }^{46}$ Hart and Tirole, 217. Here we identify the long term lease with acquisition, although later we distinguish between these governance structures when discussing the importance of relationship specific investments. Hart and Tirole assume that profit sharing enables investment costs to be internalized within the merged firm (p. 216).

${ }^{47}$ Williamson, "Transaction Cost Economics" in Handbook of Industrial Organization, 176.

${ }^{48}$ Paul L. Joskow, "Asset Specificity and the Structure of Vertical Relationships: Empirical Evidence," Journal of Law, Economics, and Organization IV (1988): 104-05.

${ }^{49}$ There are three broad transaction costs involved. First, it will be costly if not impossible for the parties to think about all the possible future contingencies. Second, it will be costly for the parties to negotiate and specify all those contingencies in a written contract. Third, monitoring 
and enforcing the contract will be costly, especially if enforcement is by a third party such as a Court that possesses much worse information about the transaction than the parties themselves possess.

Oliver Hart, Firms, Contracts, and Financial Structure, (Oxford: Clarendon Press, 1995), 23.

${ }^{50}$ In contrast to Hart and Tirole, these investment costs are not subject to profit-sharing, even under integration.

${ }^{51}$ Bolton and Whinston, 1991, 211.

${ }^{52}$ The intuition is simpler in a bilateral rather than a multilateral setting. So consider a special bilateral case of Bolton and Whinston. Both downstream firms are under a common ownership, what they dub horizontal integration. Assume that $v_{2}\left(I_{2}, s\right)=0$ for all values of $I_{2}$ and $s$. So the only relevant investment decision is choosing $I_{1}$, and ex-post trade will always take place. When the upstream and downstream assets are under separate ownership, the downstream unit's gross payoff to investing is $\frac{v_{1}}{2}$. Since the downstream firm receives only 50 cents for every dollar of social value it creates, there is underinvestment.

${ }^{53}$ There is no inefficiency in the trading decisions. Rather, the increase in investment by the integrated downstream firm $D_{i}$ raises $v_{i}$ and so leads to more occasions in which $v_{i}>v_{j}$ and there is only one unit of the input. The reduction in investment by the remaining non-integrated downstream firm $D_{j}$ reinforces this effect.

${ }^{54}$ As noted in an earlier note, the Wall Street Journal estimated that the Great Northern properties contained 500 million tons of ore, an estimate thought imprecise by industry observers. In 1906, the year the Hill lease was signed, the entire Lake Superior region, which included the Mesabi 
range, produced 38 million tons of ore.

"The Exact Quantity of Ore in the Hill Properties," The Iron Age, January 18, 1906, 280.

Ernest F. Burchard, "Iron Ore, Pig Iron, and Steel," reproduced in United States House of Representatives, Hearings Before the Committee on Investigation of the United States Steel Corporation, No. 52 (February 28, 1912), 3497.

${ }^{55}$ Bruce T. Allen, "Vertical Integration and Market Foreclosure: The Case of Cement and Concrete," Journal of Law and Economics 14 (1971): 251-274.

${ }^{56}$ Curtis Grimm, Clifford Winston, and Carol Evans, "Foreclosure of Railroad Markets: A Test of Chicago Leverage Theory," Journal of Law and Economics 35 (1992): 295-310.

${ }^{57}$ Tasneem Chipty, "Vertical Integration, Market Foreclosure, and Consumer Welfare: An Empirical Investigation," April 1995 Mimeo.

${ }^{58}$ Christopher Snyder, "Interfirm Effects of Vertical Integration: Event Studies of the U.S. Oil Industry," July 1995 Mimeo.

Christopher Snyder, "Vertical Foreclosure in the British Beer Industry," June 1995 Mimeo.

${ }^{59}$ It is theoretically possible to differentiate the responses among steel rivals by observing their heterogeneous responses to the event based upon their differential ore holdings. Unfortunately, reliable data on the ore holdings of steel companies other than US Steel during this period are not readily available.

${ }^{60}$ See Hart and Tirole, pp. 212-213. 
${ }^{61}$ Closing stock prices for the last trading day of the week were gathered from the New York Times and the Wall Street Journal. If no closing price was available for a particular week, the average of the closing bid and ask for the last trading day of the week was substituted. Finally, if neither a bid nor ask was available, then no return was calculated for that week and the subsequent week. Returns were calculated from these prices with an adjustment for dividends and stock splits.

${ }^{62}$ The Steel and Railroad companies employed are reported in Tables 2 and 3 at the end of the paper.

63“Railroad Freight Rates," The Iron Age, February 14, 1907, 498.

${ }^{64}$ John Moody, Moody's Analyses of Investments: Steam Railroads (New York: Analyses Publishing Company, 1925).

${ }^{65}$ Report of the Commissioner of Corporations on the Steel Industry, Part III: Cost of Production, Full Report, May 6, 1913, 330.

${ }^{66}$ See Mullin, Mullin, and Mullin, at 319.

${ }^{67}$ Prior to their use of steel rails, American railroads used iron rails. Of course, the Great Northern Ore lease would affect the price of iron as well as steel.

${ }^{68}$ Even if market participants anticipated the future retrenchment of the railroads, discounting would minimize the impact of these future developments.

${ }^{69}$ Miles of track operated rose from 258,784 in 1900 to 306,797 in 1905 , and reached 406,000 in 1920. Hogan, Economic History of the Iron and Steel Industry in the United States, Volume 2, 652. On the shift to all steel freight cars, see Hogan, Volume 2, 654-656. 
${ }^{70}$ The New York Times index of 50 stocks is more broadly based than the Dow Jones Industrial Average, which consisted of between 12 and 20 stocks during this period. The New York Times index is available in published sources starting in 1911. We therefore employed the list of stocks used at the start of 1911 .

${ }^{71}$ Steel Sensitivity was judged by examining the firms' primary outputs. See Table 4 at the end of the paper.

${ }^{72}$ Wall Street Journal, October 13, 1913, p.1

${ }^{73}$ Time loans were "made to stock and bond brokers and investment bankers on securities as collateral." A standard time loan required collateral "worth in the market about $130 \%$ of the amount of the loan." See Macaulay (1938), Appendix E. Since there were no Treasury Bills at this time, the rate on time loans represents the best measure of the risk free rate of interest.

74 "The Enhancement of Lake Ore Values," The Iron Age, April 19, 1906, 1340. The editors of The Iron Age commented that discussion of the transaction from time to time had been a significant stock market factor. The editors referred specifically to the stipulation of an 80 cent royalty and the guaranteed minimum tonnage. In the journal's September 20, 1906 edition, the editors commented that "although it would be premature to consider the pending arrangement a 'contract,' it...long has been such in effect because the Hill interests [have] refused to entertain proposals from other potential suitors." "The Lake Superior Ore Situation," The Iron Age, 742.

The consummation of the deal was not a certainty, however. Stories periodically reported hitches or breakdowns in negotiations. The Iron Age, May 31, 1906; "Hitch in Ore Lease to Steel Corporation," The New York Times, February 25, 1906, 3. Such occurrences were considered as 
event candidates but they did not produce statistically significant results for the Great Northern Preferred or US Steel, possibly because the reports of negotiation breakdowns could be interpreted as posturing by the parties for bargaining benefit. As part of the Eckbo-Stillman methodology, these event candidates were therefore not considered as events.

${ }^{75}$ These certificates were not created until after the lease was signed, and so they cannot be used in the earlier analysis.

${ }^{76}$ Sara Fisher Ellison and Wallace P. Mullin, "Economics and Politics: The Case of Sugar Tariff Reform," Journal of Law and Economics 38 (1995) 351.

${ }^{77}$ This leakage should not be surprising, given the need for meetings between the participants to hammer out terms of the agreement.

For example, the Wall Street Journal headlined on Thursday, October 4, 1906, "Hill Ore Properties: Announcement of Terms a Question of a Few Days Only." (p. 4). This followed on reports earlier in the week on the progress of the deal. The lease terms were formally announced on Friday, October 5, at $4 \mathrm{pm}$. So this news was available to the market for its half day of trading on Saturday. "Ore Deal Closed," Wall Street Journal, October 6, 1906, p. 1.

${ }^{78}$ Specifically, they allowed the true event response to occur on one of three days, so the event-date uncertainty was limited to a three-day period. They then compared the results from estimating with daily data and cumulating residuals to estimating the market model and computing excess returns over three-day holding periods. They found that the three-day market model approach did slightly better in detecting abnormal performance, although this difference was not statistically significant. 
Thomas Dyckman, Donna Philbrick, and Jens Stephan, "A Comparison of Event Study Methodologies Using Daily Stock Returns: A Simulation Approach," Journal of Accounting Research 22, Supplement (1984): 16-18.

${ }^{79}$ The Great Northern later did following through on that intention through the issuance of the Great Northern Ore Certificates which were distributed on a one for one basis to the common stockholders. "Hill Cuts Ore Melon into 1,500,000 Pieces," The New York Times, November 22, 1906, 15.

80 "Great Ore Deal Signed; Stocks Up in Advance," The New York Times, October 6, 1906, 10. Note that this is a raw return as distinct from the market adjusted returns cited in the balance of this paper.

81 "Ore Deal Closed," The Wall Street Journal, October 6, 1906, 1. Even James Hill commented that he believed the deal to have greater significance for US Steel than for the Great Northern. "James J. Hill Prefers Credit to Ready Cash," The New York Times, October 7, 1906, 1.

${ }^{82}$ The test is based on Shapiro and Wilk (1965), as implemented by Royston (1992).

${ }^{83}$ The p-value from the test on excess railroad returns was 0.59 .

84"A Remarkable Ore Movement; The Oliver Mining Company's Model Town," The Iron Age, July $18,1907,160$.

${ }^{85}$ The map is reprinted from Iron Age, February 1, 1906, 420.

86 “A Monumental Year in Iron and Steel," The Iron Age, January 3, 1907, 56.

87 "Great Northern Ore Land Earnings," The Iron Age, December 6, 1906, 1515. 
${ }^{88}$ Part of the delay in extraction and even preparation appeared to result from the gap between the announcement of the lease and the time when the contract was officially executed. "Ore Shipments are Large," The Iron Age, August 29, 1907, 559.

89 "Hill Lands Show More Ore Than Estimated," The Iron Age, October 15, 1908, 1082.

${ }^{90}$ US Steel's annual reports did not separately identify the expenditures made in developing the Great Northern and related properties. We do know, however, that US Steel developed eight mines on the Hill lands, and other reports indicate a conservative development cost of $\$ 1$ million per mine. We consider our estimated additional expenditures of $\$ 4$ million conservative since US Steel clearly made exploration expenditures throughout the leased lands, and not merely on these eight mines. "Plans for the Great Northern Ore Properties," Iron Age, May 8, 1913, 1131.

${ }^{91}$ Conversion to 1994 dollars based on Bureau of Labor Statistics Producer Price Index.

${ }^{92}$ Bureau of Corporations, Report of the Commissioner, Part I, 209.

${ }^{93}$ Dwight E. Woodbridge, "The Lake Iron Ore Trade in 1906," The Iron Age, January 3, 1907, 60.

94 "The Centers of Pig Iron Production and of Lake Ore Consumption," The Iron Age, March $14,1907,835$.

95 “The New Steel Plant at Duluth," Iron Age, November 23, 1911, 1196.

${ }^{96}$ United States Steel Annual Reports for 1913 (p. 27), 1914 (p. 27), 1915 (p. 26), and 1916 (p. 28).

${ }^{97}$ United States Steel Annual Report, 1915, 27. 
${ }^{98}$ The Great Northern was required to make improvements in its railroad transportation system, with some of improvements beginning even before the lease was finally signed. "Early Lake Ore Shipments Wanted" The Iron Age, March 8, 1906, Although investments made before a contract is signed are even more prone to opportunism than those made following a contract, the Great Northern's precontractual preparations were limited to developing its own property in a manner which would continue to have significant (albeit smaller) value independent of the ultimate consummation of the Hill Ore Lease.

99 "Steel Corporation Payments for Hill Ore," The Iron Age, January 12, 1911, 163.

${ }^{100}$ Testimony of James J. Hill, United States House of Representatives, Hearings Before the Committee on Investigation of the United States Steel Corporation, No. 49 (February 13, 1912), 3240.

${ }^{101}$ Testimony of James J. Hill, United States House of Representatives, Hearings Before the Committee on Investigation of the United States Steel Corporation, No. 49 (February 13, 1912), 3214.

${ }^{102}$ United States House of Representatives, Hearings Before the Committee on Investigation of the United States Steel Corporation, No. 49 (February 13, 1912), 3212, and No. 8 (June 14, 1911), 438.

${ }^{103}$ Report of the Commissioner, Part I, 318-23.

104 "Some Oliver Iron Mining Company's Large Properties," The Iron Age, March 8, 1906, 858.

${ }^{105}$ Brief of US Government, paragraph 146. See also, United States House of Representatives, Hearings Before the Committee on Investigation of the United States Steel Corporation, No. 53 (February 28, 1912), 4340-4347, for a sample US Steel coal contract in which US Steel guaranteed 
the coal mining company would be the exclusive supplier of coal for specified purposes for the duration of the 25 year contract.

${ }^{106}$ The Bureau conceded in its report that US Steel did not have a monopolistic position in the ownership of coal and coke property. Report of the Commissioner, Part I, 376. Quantitatively, total domestic production of coal in 1906 was $414,157,278$ short tons whereas only $55,746,374$ short tons of coal were used in 1906 to produce coke, the factor relevant to the steel production process. United States Geological Survey, Mineral Resources of the United States, 1906, 564, 768. This suggests a vast reservoir of uncommitted capacity available to prevent foreclosure.

${ }^{107}$ Joskow, "Contract Duration," 168-83.

${ }^{108}$ The Great Northern Properties were spun off following consummation of the Hill Ore Lease. The organizational structure of the properties was a trust with publicly trade ore certificates.

109 "New Stripping at Hill Mines," The Iron Age, June 13, 1912, 1490.

110 “Great Northern Ore Developments," The Iron Age, July 25, 1912, 216.

${ }^{111} \mathrm{Id}$.

112 "New Leases of Hill Iron Mines," The Iron Age, October 15, 1914, 920; "Hill Iron Ores in 1915," The Iron Age, December 10, 1914, 1353.

${ }^{113}$ Great Northern Iron Ore Properties, Eleventh Annual Report of the Trustees for the Period Ended December 31st 1917, 16.

${ }^{114}$ Report of the Federal Trade Commission on the Control of Iron Ore, 8. 
${ }^{115}$ One difference between the character of the leases was that a few of these leases were entered into as a partial joint venture so that the royalty consisted of a percentage of the ore mined. Great Northern Iron Ore Properties, Eighth Annual Report of the Trustees for the Period Ended December 31st 1914, 20. The percentage royalty method was not the ordinary lease provision for the Great Northern Ore Properties, but it may have been a necessary innovation because many of the smaller lessees had relatively modest capitalizations and could not afford to engage in largescale exploitation of ore properties. Report of the Federal Trade Commission on the Control of Iron Ore, 9 .

116 "Jones \& Laughlin Ore Lease," The Iron Age, March 8, 1917, 617.

${ }^{117}$ A mining lease with Butler Brothers executed in August 1913 for mines surrendered by US Steel included a take or pay provision and required the lessee to erect a washing plant for the concentration of the property's sandy ores. Great Northern Iron Ore Properties, Seventh Annual Report of the Trustees for the Period Ended December 31st 1913, 18.

${ }^{118}$ Parsons and Ray, "US Steel Consolidation," 119. The Bureau Report found the royalty with its annual escalation clause to be "absolutely unprecedented in the Lake ore trade," an above market rate with the "only reasonable explanation [being] that the Steel Corporation desired to prevent this ore either from being mined and sold to independent producers, thus possibly depressing the price of ore, or from being utilized by the Hill interests to build up a new and dangerous competitor in the iron and steel business." Report of the Commissioner, Part I, 48. Finally, the Department of Justice argued the royalty was "unprecedentedly large" when filing its brief on the issue of anticompetitive intent. US Government Brief, United States vs. United States Steel, Filed 1912 in the Federal District Court of New Jersey, paragraph 118. 
${ }^{119}$ During the early years of the lease, US Steel fell behind on its guaranteed minimums obligation, but ultimately caught up to receive full value before cancellation of the lease in 1915. "Ore Mining on the Great Northern Properties," The Iron Age, June 29, 1911, 1569.

${ }^{120}$ This feature is examined by Scott E. Masten, "Minimum Bill Contracts: Theory and Policy," Journal of Industrial Economics, 37 (1988): 87.

${ }^{121}$ Masten and Crocker, "Efficient Adaptation," 1085. In addition, although the Great Northern relied upon the economic incentives established by the principal terms of the lease to motivate US Steel to invest adequately in the property, the lease also include specific obligations for continued exploration including minimum drilling requirements. "The Great Northern Output," The Iron Age, March 26, 1908, 1012. US Steel easily exceeded the specific drilling obligation on account of its overall incentive structure. Great Northern Iron Ore Properties, Annual Report of the Trustees for the Period Ended 1910, 2. See also Joskow (1985), (1988) for a consideration of take or pay provisions in modern coal contracts.

122 "The Lake Iron Ore Situation," The Iron Age, April 12, 1906, 1267.

123 "Ore Shipments Not to be Pushed-Mesaba Operations Will Keep Up," The Iron Age, March $19,1908,930$.

${ }^{124}$ Report of the Commissioner, Part I, 48.

${ }^{125}$ Bureau of Corporations, Report of the Commissioner, Part III, 41.

${ }^{126}$ Although historical accounting numbers must be approached with particular caution, due to non-uniformity in practices, a large portion of these reported book costs involved prices that can 
be verified independently. For example, the freight rate from the mines to Superior Wisconsin was a flat 80 cents per ton. The lake freight from Superior to Lake Erie ports "were the actual rates paid upon the tonnages shipped." Report of the Commissioner, Part III, 39.

${ }^{127}$ Bureau of Corporations, Report of the Commissioner, Part III, 41.

${ }^{128}$ Bureau of Statistics, American Iron and Steel Institute, Statistics of the American and Foreign Iron Trades for 1912,29

${ }^{129}$ Many of the tracts on the Mesabi and Vermilion Ranges in Minnesota were owned by the state of Minnesota, and were initially leased by the state on a royalty payment of 25 cents per gross ton mined. Bureau of Corporations, Report of the Commissioner, Part III, 28.

${ }^{130}$ Report of the Commissioner, Part III, 32.

${ }^{131}$ Bureau of Statistics, American Iron and Steel Institute, Statistics of the American and Foreign Iron Trades for 1912,26

132 "Great Northern Ore Land Earnings," Iron Age, December 6, 1906, 1515.

${ }^{133}$ US Steel guaranteed the specific performance of the Great Western Mining Company, its subsidiary that actually leased the Hill Ore lands. The quotation is taken from an excerpt from that guarantee, which recapitulates many but unfortunately not all of the terms of the lease.

United States House of Representatives, Hearings Before the Committee on Investigation of the United States Steel Corporation, No. 49 (February 13, 1912), 3250.

134 "The Hill Ore Properties Leased," The Iron Age, October 11, 1906, 953. For an analysis of profit margins on ore freight, see Report of the Commissioner, Part III, 379-80. 
${ }^{135}$ Benjamin Klein, Robert Crawford, and Armen Alchian, "Vertical Integration, Appropriable Rents, and the Competitive Contracting Process," Journal of Law and Economics, 21 (1978).

${ }^{136}$ United States House of Representatives, Hearings Before the Committee on Investigation of the United States Steel Corporation, No. 49 (February 13, 1912), 3249.

137 ur The Lake Superior Mining Institute," Iron Age, July 8, 1908, 109.

${ }^{138}$ Dwight E. Woodbridge, “Lake Superior Iron Mining in 1907-Improved Methods Introduced," The Iron Age, January 9, 1908, 140.

139 "The Lake Superior Mining Institute," The Iron Age, July 9, 1908, 109. "A Large Iron Ore Concentrating Plant," The Iron Age, September 24, 1908, 861. United States Steel, Annual Report $1910,223$.

${ }^{140}$ Dwight E. Woodbridge, "Concentrating the Lean Ores on the Mesaba Range," The Iron Age, January 6, 1910, 51.

141 "Shipments from the Hill Mine-A Large Output for 1911-Concentration at Coleraine," The Iron Age, June 1, 1911, 1326. US Steel soon decided to begin production of a second Mesabi concentrating plant. "Lake Superior Mining Notes-Another Mesaba Concentrating Plant," The Iron Age, August 3, 1911, 264.

${ }^{142}$ As of 1907 , the royalty for ore that fell to as low as 49 percent iron content would be 36.8 cents, with the royalty for lower grades either subject to arbitration or set at 30 cents per ton.

${ }^{143}$ See "Hill Ore Lands in 1913," The Iron Age, April 9, 1914, 914, on the relatively low percentage of low-grade ores mined by US Steel. 
${ }^{144}$ Woodbridge, "The Hill Ore Properties," The Iron Age, January 4, 1906, 26. In 1906, the lack of exploration justified the statement that "few estimates [of the tonnages in the Great Northern Properties], however moderate, are more than guesses." Furthermore, the uncertainty associated with new explorations was substantial. "If one in fifty of the explorations undertaken on lands of new selection is successful in finding a mine of reasonable size and grade, the explorer may consider himself fortunate." "Few Promising Ore Explorations," The Iron Age, August 23, 1906, 491.

${ }^{145}$ The editors of The Iron Age conjectured that "the whole transaction is based on the belief that the bulk of the iron ore in the United States that can be carried at reasonable freights to advantageous assembling points for fuel and ore is known today." "The Transfer of the Hill Ore Lands," The Iron Age, October 11, 1906, 950. Although the cost of transportation is a significant factor, the parties also had to consider international ore discoveries. For example, a major discovery of Cuban ore in 1907 was described as the most important ore discovery since the Mesabi range itself in 1891. "The New Cuban Iron Ore Deposit," The Iron Age, August 15, 1907, 438. Unsurprisingly, the enhancement in lake ore values signaled by the Hill Ore Lease accelerated the search for new foreign supplies of ore. "Heavy Iron Ore Imports to the United States in 1910," The Iron Age, September $9,1909,785$.

${ }^{146}$ Keith J. Crocker and Scott E. Masten, "Mitigating Contractual Hazards: Unilateral Options and Contract Length." Rand Journal of Economics, 16 (1988).

147 "Plans for the Great Northern Ore Properties," The Iron Age, May 8, 1913, 1131.

Great Northern Iron Ore Properties, Sixth Annual Report of the Trustees for the Period Ended December 31st, 1912, 16. 
${ }^{148}$ Great Northern Iron Ore Properties, Annual Report of the Trustees for the Period Ended December 31, 1914, 22.

${ }^{149}$ United States Steel Corporation, Thirteenth Annual Report of the United States Steel Corporation for the Fiscal Year Ended December 31, 1914, 28, discusses the end of the lease.

${ }^{150}$ Of the more than 39,000 acres of ore properties leased, the Great Northern held approximately 20,000 acres in fee; 16,000 acres in fee, jointly held; and 3,000 acres by long-term lease. Report of the Commissioner, 261 n. 1.

${ }^{151}$ An alternative ownership arrangement would have had US Steel acquire both the Great Northern Ore Properties and the Great Northern Railway itself. The acquisition of the Railway might have generated diseconomies, however.

${ }^{152}$ United States House of Representatives, Hearings Before the Committee on Investigation of the United States Steel Corporation, No. 52 (February 28, 1912), 3542-3543.

153“The Hill Ore Lease," Iron Age, March 28, 1907, 986.

${ }^{154}$ The Trustees for the Great Northern Iron Ore Properties reported new leases each year in the annual report. In 1917, the Trustees commented that plans for the wholly undeveloped mining lands had not yet been determined. Great Northern Iron Ore Properties, Eleventh Annual Report of the Trustees for Period Ending December 31, 1917, 16. Inspection of the annual reports for the years 1918 through 1927 make no mention of additional development or leases of undeveloped territories. 
Table 1: Average Estimated Event Responses

(t statistics in parentheses)

\begin{tabular}{||lcc|cc||}
\hline EVENT & USSTEEL & GN RAILWAY & STEEL RIVALS & RAILROADS \\
\hline \multirow{2}{*}{ LEASESIGN } & .04130 & -.01420 & -.01194 & .00959 \\
& $(1.9865)$ & $(-0.6272)$ & $(-0.7674)$ & $(1.8372)$ \\
& & & & \\
\hline
\end{tabular}

\section{Tables}


Table 2: Sample of Steel Companies

United States Steel

American Steel Foundries

Colorado Fuel and Iron

National Enameling and Stamping

Republic Iron and Steel

Sloss Sheffield

Tennessee Coal and Iron

U.S. Cast Iron Pipe and Foundry 
Table 3: Sample of Steam Railroads

Atchison, Topeka, and Santa Fe

Atlantic Coast Line

Baltimore and Ohio

Central of New Jersey

Chesapeake and Ohio

Chicago Great Western

Chicago, Milwaukee, and St.Paul

Chicago and Northwestern

Cleveland, Cincinnati, Chicago and St. Louis

Colorado Southern

Delaware and Hudson

Denver and Rio Grande

Erie

Erie First Preferred

Great Northern Railway Preferred

Illinois Central

Iowa Central

Kansas City Southern

Louisville and Nashville

Minneapolis, St. Paul and Sault Ste. Marie

Missouri, Kansas and Texas

Missouri Pacific

New York Central

New York, Chicago and St. Louis

New York, New Haven and Hartford

New York, Ontario and Western

Norfolk and Western

Northern Pacific

Pennsylvania

Reading

Rock Island

Southern Pacific

Southern Railway

St. Louis Southwestern

Texas Pacific

Union Pacific

Wabash Common

Wabash Preferred

Wheeling and Lake Erie

Wisconsin Central 
Table 4: Composition of Industrials

Firm Primary Outputs

High Steel Sensitivity:

Amalgamated Copper

American Car \& Foundry

American Locomotive

American Smelting \& Refining

International Steam Pump

National Lead

Pressed Steel Car

Republic Iron and Steel

U.S. Steel

Westinghouse Co.

Copper mining

Freight \& Passenger Cars

Locomotives

Bar Gold \& Silver, pig lead

Pumps for mining \& oil exploration

Lead products

Freight Cars

Steel Products

Steel Products

Electric lighting \& power machinery

Low Steel Sensitivity:

American Agricultural Chemical

American Beet Sugar

Fertilizer, glue, gelatin

American Cotton Oil

Sugar

Cotton Seed Products

Central Leather

Sole leather

Consolidated Gas

People's Gas

Gas \& Electricity, New York City

U.S. Rubber

Gas, Chicago

Rubber products

Virginia Carolina Chemical

Acids, chemicals, fertilizers

Western Union

Telegraph service

Primary outputs were found in Malcolm R. Burns, "An Empirical Analysis of Stockholder Injury Under Section 2 of the Sherman Act," Journal of Industrial Economics. 31 (June 1983), p. 349, as supplemented by Moody's Analyses of Public Utilities and Industrials, 1918. 


$$
\text { Figure } 1
$$

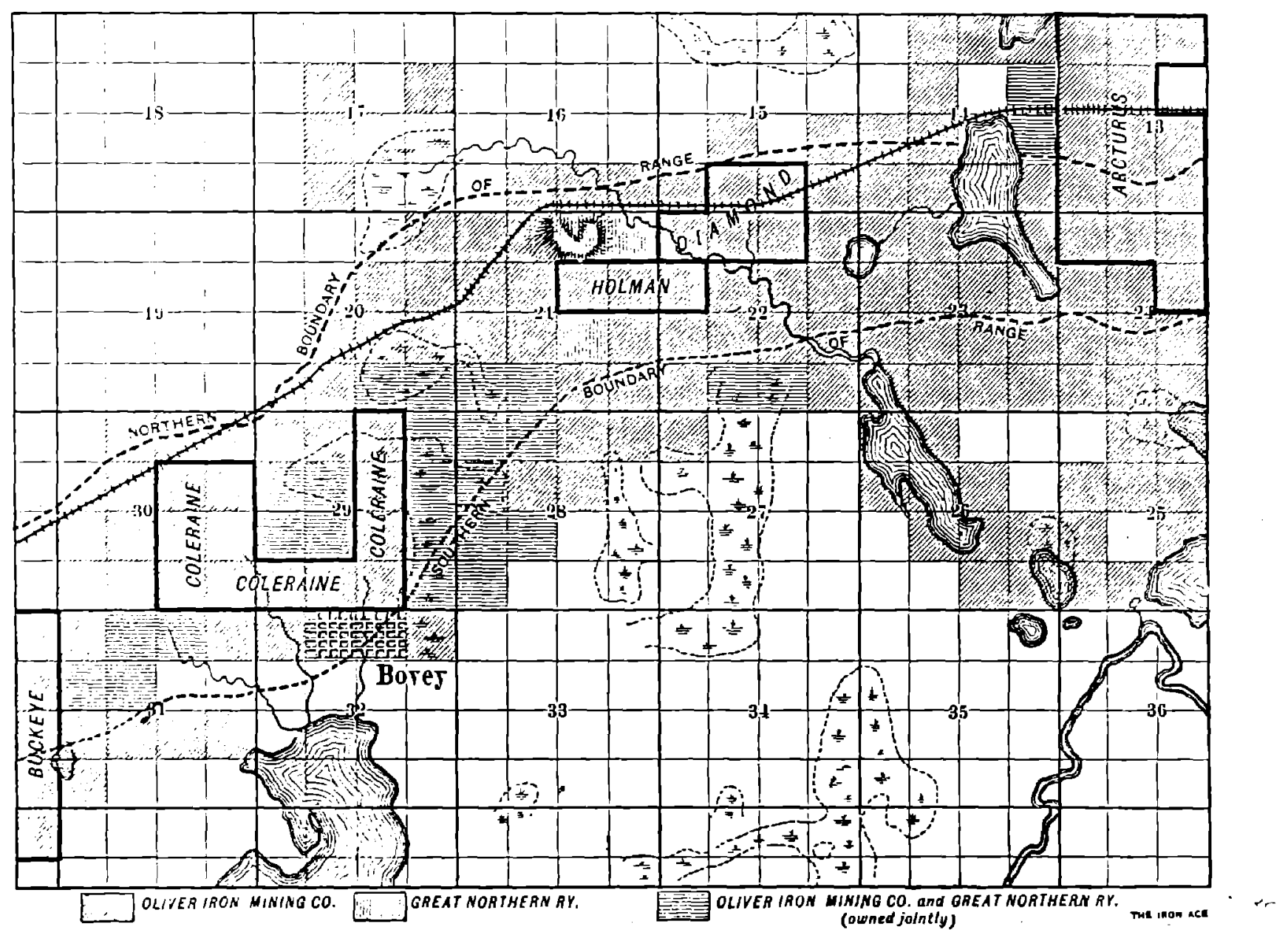

